ARCHEION, T. CXX

WARSZAWA 2019

ISSN 0066-6041

e-ISSN 2658-1264

DOI 10.4467/26581264ARC.19.012.11821

KAROL NABIAŁEK

ORCID 0000-0002-6626-4071

karol.nabialek@us.edu.pl

(Uniwersytet Śląski w Katowicach)

\title{
KSIĘGI MIEJSKIE PROSZOWIC Z XV-XVIII W. STUDIUM KODYKOLOGICZNE
}

Słowa kluczowe: księgi miejskie, kancelaria miejska, księgi ławnicze, rękopisy

\section{Streszczenie}

Artykuł stanowi wstępne studium dotyczące ksiąg miejskich Proszowic. Było to miasto królewskie położone w dawnym województwie krakowskim, zaliczane do II kategorii podatkowej, lokowane w 1358 r. przez Kazimierza Wielkiego. Sporządzono opisy kodykologiczne 10 zachowanych i zidentyfikowanych rękopisów. Ponadto zostały zinwentaryzowane rozproszone fragmenty ksiąg ławniczych, radzieckich i radziecko-ławniczych z XVII-XVIII w. Najstarsza księga miejska (1. 1418 1456) zawiera głównie wpisy rady, w części dokonane z udziałem wójta i ławników. Jeden z tomów to księga rachunkowa $z$ lat 1768-1786. Pozostałe rękopisy to księgi ławnicze, a więc dokumentacja działalności sądu ławniczego (1. 1449-1588) oraz księga kryminalna, która zawiera wpisy z lat 1581-1686 dotyczące spraw karnych rozpatrywanych przez sąd miejski. W ramach ksiąg wójtowsko-ławniczych można zasadniczo wyróżnić dwie serie, które były prowadzone od XV w. Pierwsza początkowo miała postać składek bez oprawy, natomiast druga to kodeksy, czyli rękopisy oprawione. Oprócz czterech najstarszych rękopisów pozostałe księgi miejskie Proszowic nie były dotąd znane i wykorzystywane w literaturze. 
KAROL NABIAEEK

ORCID 0000-0002-6626-4071

karol.nabialek@us.edu.pl

(University of Silesia in Katowice)

\title{
PROSZOWICE TOWN RECORDS FROM $15^{\mathrm{TH}}$ TO $18^{\mathrm{TH}}$ CENTURY. THE CODICOLOGY STUDY
}

Keywords: town records, municipal chancellery, bench records, manuscripts

\begin{abstract}
The article is a preliminary study of Proszowice town records. Proszowice was a royal town located in the former Cracow voivodeship, classified into $2^{\text {nd }}$ tax category. The town charter was granted in 1358 by Casimir the Great. Codicological descriptions of 10 extant and identified manuscripts were prepared. Moreover, an inventory was prepared of dispersed fragments of bench records, council records and bench/council records of $17^{\text {th }}-18^{\text {th }}$ century. The oldest book of town records (1418-1456) includes mostly the council entries, in part made with participation of the mayor and aldermen. One of the volumes is an accounting ledger from 1768-1786. The remaining manuscripts are bench records, i.e. the documentation of the magistrate court (1449-1588) and the book of criminal records, which comprises entries from 1581-1686 pertaining to criminal cases examined by the town court. The mayor/aldermen records can be essentially divided into two series, kept from $15^{\text {th }}$ century. The first was initially composed of unbound folded sheets, the other comprises codices, i.e. bound manuscripts. Other than the oldest four manuscripts, Proszowice town records were hereto not known or used in literature.
\end{abstract}




\section{Wstęp}

Istotnym problemem polskiej historiografii jest brak badań podstawowych, a w szczególności niewielki stopień opracowania źródeł historycznych w zakresie edycji, jak też inwentaryzacji zachowanych rękopisów. Bardzo wyraźny jest ten brak w odniesieniu do wytworów kancelarii miejskich. Dokumentacja własna miast polskich z okresu średniowiecza i epoki nowożytnej, w ramach której główne znaczenie odgrywały księgi wpisów, zachowała się tylko w niewielkim stopniu. Są wprawdzie ośrodki miejskie, których zachowana spuścizna aktowa jest bogata - zarówno większe (Kraków), średnie (Przemyśl) jak i mniejsze (Radziejów). Stanowią one jednak wyjątki. Wiele miast, zwłaszcza z Polski centralnej, utraciło swą najstarszą dokumentację, co było spowodowane różnymi czynnikami - od warunków przechowywania, przez różnego rodzaju klęski elementarne, aż po wydarzenia polityczne. Największym ciosem dla źródeł miejskich była zagłada zbiorów Archiwum Głównego w Warszawie we wrześniu 1944 r. $^{2}$

Wiedza o zasobie zachowanych akt miejskich jest jednak co najmniej niewystarczająca. W zasadzie brak opracowań oraz pomocy archiwalnych, które zawierałyby pełny wykaz ksiąg miejskich z terenu Polski dla okresu przedrozbiorowego czy nawet tylko średniowiecza. Publikowane zestawienia powstawały jedynie przy okazji różnych prac tematycznych, najczęściej ograniczonych terytorialnie i czasowo. Opracowane zostały wprawdzie dość szczegółowe inwentarze ksiąg miejskich, ale dotyczą zasobów z konkretnych archiwów, jak np. akta miejskie przechowywane w archiwach państwowych w Krakowie (miasta Kraków, Kazimierz, Kleparz) ${ }^{3}$, Lwowie (Lwów) ${ }^{4}$ czy w Przemyślu (miasta Przemyśl, Jarosław $)^{5}$. Powstało też kilka prac poświęconych kancelariom poszcze-

${ }^{1}$ Podziękowania dla pani Elżbiety Knapek za lekturę pierwotnej wersji tekstu, cenne uwagi i uzupełnienia.

${ }^{2}$ A. Wolff, Akta partykularne przedrozbiorowe Archiwum Gtównego 1381-1835, [w:] Straty archiwów i bibliotek warszawskich w zakresie rękopiśmiennych źródet historycznych, t. 1. Archiwum Gtówne Akt Dawnych, red. A. Stabelski, Warszawa 1957, s. 175-221; A. Bartoszewicz, Średniowieczne księgi sądowe polskich miast - dzieje powstania zespołów i kolekcji, [w:] Dziedzictwo utracone - dziedzictwo odzyskane, red. A. Kamler, D. Pietrzkiewicz, Warszawa 2014, s. 159-173.

${ }^{3}$ Katalog Archiwum Aktów Dawnych miasta Krakowa, [t.] 2. Rękopisy. Nr. 1-3568, Kraków 1915 (oprac. zbior. przygotowane przez zespół archiwistów pod red. S. Krzyżanowskiego); Inwentarz archiwum miasta Kazimierza pod Krakowem 1335-1802, oprac. M. Friedberg, Warszawa 1966; Inwentarz archiwum miasta Kleparza pod Krakowem 1366-1794, oprac. Z. Wenzel-Homecka i Z. Wojas, Warszawa 1968.

${ }^{4}$ Archiwum Akt Dawnych miasta Lwowa. A: Oddział Staropolski, t. 3. Ksiegi i akta administracyjno-sadowe 1382-1787; t. 4. Księgi rachunkowe (lonerskie) 1404-1788, oprac. K. Badecki, Lwów 1935-1936.

${ }^{5}$ Dokładne inwentarze opracowano zwłaszcza dla akt miejskich Przemyśla, gdyż dawny katalog autorstwa Jana Smołki został poprawiony i uzupełniony pod koniec XX w., a ponadto poprzedzony studium o dziejach tego zespołu. Dzięki tym opracowaniom mamy bardzo dobrą orientację w spuściź- 
gólnych miast (Kraków, Poznań, Lublin, Toruń, Kazimierz, Chrzanów), w których opisano spuściznę aktową tych ośrodków ${ }^{6}$.

Nie zostały jednak zgromadzone kompletne informacje o księgach miejskich przechowywanych we wszystkich możliwych do przejrzenia kolekcjach archiwalnych i bibliotecznych ${ }^{7}$. Nie dysponujemy tego typu wykazami nawet dla poszczególnych regionów, jak np. Małopolska ${ }^{8}$. Nie zestawiono nawet ksiąg z samego tylko średniowiecza. Powyższe uwagi odnoszą się zwłaszcza do ośrodków mniejszych, o księgach których informacje w literaturze są dość przypadkowe9

nie aktowej miasta Przemyśla. Jest to jednak przypadek szczególny, gdyż dotyczy zespołu, który nie uległ rozproszeniu i jest przechowywany w jednym archiwum. Zob.: J. Smołka, Katalog Archiwum Aktów Dawnych miasta Przemyśla, Przemyśl 1927, s. 39-87; J. Krochmal, Akta miasta Przemyśla (1402-1944), t. 1. Przewodnik po zespole archiwalnym, Przemyśl 1995, t. 2. Akta miasta Przemyśla (1356-1389), 1402-1944 (1945-1983), oprac. J. Krochmal, Przemyśl 2000; J. Smołka, Katalog Archiwum Aktów Dawnych miasta Jarosławia, Jarosław 1928, s. 17-21; M. Proksa, Przewodnik po zespole Akta miasta Jarostawia, Przemyśl 1994, s. 40-44.

${ }^{6}$ M. Friedberg, Kancelaria miasta Krakowa do polowy XVIII wieku, „Archeion” 1955, t. 24, s. 277-304; idem, Kancelaria miasta Kazimierza pod Krakowem 1355-1802, „Archeion” 1962, t. 36, s. 137-170; B. Wyrozumska, Kancelaria miasta Krakowa w średniowieczu, Kraków 1995; H. Piskorska, Organizacja władz i kancelarii miasta Torunia do 1793 roku, Toruń 1956; W. Maisel, Sadownictwo miasta Poznania do końca XVI wieku, Poznań 1961; I. Radtke, Kancelaria miasta Poznania do roku 1570, Poznań 1967; M. Stankowa, Kancelaria miasta Lublina XIV-XVIII wieku, Warszawa 1968; M. Starzyński, Średniowieczny Kazimierz, jego ustrój i kancelaria, Kraków 2015; D. Lisowicz-Żurek, Kancelaria małego miasta - organizacja, funkcje, znaczenie na przykładzie Chrzanowa $w X V-X V I$ wieku, „Średniowiecze Polskie i Powszechne” 2015, t. 7(11), s. 228-240.

${ }^{7}$ W 1984 r. została podjęta wprawdzie inicjatywa Naczelnej Dyrekcji Archiwów Państwowych dotycząca ujednolicenia metod opracowania akt miejskich z okresu księgi wpisów. Wytyczne te miały jednak charakter metodyczny i przeznaczone były na użytek roboczy dla archiwistów (zob.: Pismo okólne nr 4 Naczelnego Dyrektora Archiwów Państwowych z dnia 22 grudnia 1984 r. Wskazówki do opracowania akt miejskich z okresu „księgi wpisów”) Nie powstał jednak centralny inwentarz gromadzący informacje o wszystkich księgach miejskich z terenu ziem polskich przechowywanych w archiwach państwowych. Nie spełnia takiej funkcji serwis: www.szukajwarchiwach.gov.pl/. Jest to baza zintegrowana, ale zawartość informacji dotyczących zasobu zależy od stopnia ich opracowania w danym archiwum.

${ }^{8}$ Nie dysponujemy dla ksiąg miejskich analogicznym opracowaniem, jakie sporządziła Janina Bielecka dla ksiąg grodzkich i ziemskich z szeroko rozumianej Wielkopolski, które było efektem wieloletniego porządkowania i opracowywania zbioru ksiąg sądowych zgromadzonych w Poznaniu (eadem, Inwentarze ksiag archiwów grodzkich i ziemskich Wielkopolski XIV-XVIII wieku. Województwa poznańskie, kaliskie, gnieźnieńskie, inowrocławskie, Poznań 1965).

9 Tylko w ograniczonym stopniu informacje o zachowanych księgach miejskich z terenu Polski zestawił Henryk Samsonowicz (idem, Średniowieczne ksieggi sądowe matych miast w Polsce, [w:] Homines et societas. Czasy Piastów i Jagiellonów. Studia historyczne ofiarowane Antoniemu Gąsiorowskiemu w sześćdziesiata piąta rocznicę urodzin, Poznań 1997, s. 477-484). Również informacje Marcina Starzyńskiego, uzupełniające wykaz Samsonowicza dla miast z terenu woj. krakowskiego, są dalekie od stanu rzeczywistego (idem, Nad średniowiecznymi księgami rachunkowymi, „Roczniki Historyczne" 2008, r. 74, s. 168-169). Podobnie można powiedzieć o zestawieniach dokonanych w pracach Agnieszki Bartoszewicz, choć badaczka ta wykorzystała i scharakteryzowała dużą liczbę średniowiecznych ksiąg z terenu Polski, zob.: eadem, Czas w matych miastach. Studium z dziejów kultury umysłowej późnośredniowiecznej Polski, Warszawa-Pułtusk 2003, s. 17-24; eadem, Piśmien- 
Stąd każdy badacz zajmujący się problematyką miejską średniowiecznej i nowożytnej Polski jest zmuszony prowadzić własne poszukiwania akt miejskich poprzez kwerendy w różnych archiwach i bibliotekach. Wiąże się to jednak $\mathrm{z}$ różnymi trudnościami ${ }^{10}$.

Dobrą ilustracją skali tego problemu jest przykład Proszowic, miasta królewskiego (wchodzącego w skład dóbr wielkorządowych), położonego w województwie krakowskim. Pomimo zachowania się średniowiecznych ksiąg tego ośrodka, w dodatku jak na warunki polskie dość wczesnych (w najstarszej części sięgających drugiej dekady XV w.), przechowywanych w znanych instytucjach, mianowicie w Archiwum Narodowym w Krakowie (dalej: ANK) oraz w Bibliotece Naukowej Polskiej Akademii Umiejętności i Polskiej Akademii Nauk (dalej: BPAU), materiały te nie zostały dotąd opracowane i tylko w niewielkim stopniu wykorzystywano je w badaniach naukowych. Jerzemu Wyrozumskiemu i Feliksowi Kirykowi zawdzięczamy wyodrębnienie najstarszych akt miejskich Proszowic z nieuporządkowanych jednostek archiwalnych zawierających akta miasta Lelowa ${ }^{11}$. Do średniowiecznych ksiąg Proszowic sięgał przede wszyst-

ność mieszczańska w średniowiecznej Polsce, Warszawa 2012, s. 14-21; eadem, Urban literacy in late medieval Poland, Turnhout 2017 (Utrecht studies in medieval literacy 39), s. 7-19, 419-423. Zakres wykorzystanych ksiąg miejskich mniejszych ośrodków został poszerzony ostatnio w katalogu testamentów opracowanym pod kierunkiem wspomnianej badaczki (Testamenty z ksiag sądowych matych miast polskich do 1525 roku, oprac. A. Bartoszewicz, K. Mrozowski, M. Radomski, K. Warda, red. A. Bartoszewicz, Warszawa 2017 - zwłaszcza zestawienie na s. 8-17). Zamieszczony w publikacji obszerny wykaz ksiąg miejskich został jednak w naturalny sposób ograniczony tylko do jednostek, w których spodziewano się odnaleźć testamenty. Dużą grupę ksiąg miejskich z terenu woj. lubelskiego z epoki przedrozbiorowej zestawił Janusz Łosowski, jednak jego cenne opracowanie ogranicza się do jednej kategorii własnościowej, tj. do ośrodków szlacheckich (idem, Kancelarie miast szlacheckich województwa lubelskiego od XV do XVIII wieku, Lublin 1997, s. 82-105, 251-252). Grupę ksiąg miejskich z okresu nowożytnego, głównie miast małopolskich i ruskich, wykorzystał Marian Mikołajczyk, a zawarte w jego pracach zestawienia bibliograficzne są bardzo przydatne. Autor ten jednak głównie zajmował się aktami spraw kryminalnych (idem, Przestępstwo i kara w prawie miast Polski poludniowej XVI-XVIII wieku, Katowice 1998, s. 15-16, 276-278; idem, Proces kryminalny w miastach Matopolski XVI-XVIII wieku, Katowice 2013, s. 19-20, 575-576). Są to jednak tylko przykłady naukowego wykorzystania dużej grupy akt miejskich, które z założenia nie mogą zastąpić inwentaryzacji i opracowania źródeł.

10 Ten złożony problem opisała trafnie Agnieszka Bartoszewicz, (choć uwaga ta odnosi się do zasobu Archiwum Głównego Akt Dawnych, można ją jednak uznać za stwierdzenie o charakterze ogólnym), eadem, Średniowieczne księgi sądowe..., s. 171-172: „Odnalezienie interesujących materiałów wymaga od badacza wiedzy i umiejętności korzystania z różnego rodzaju pomocy archiwalnych, ponieważ nie dysponujemy żadnym zbiorczym zestawieniem informującym o przechowywanym zasobie archiwum źródłach proweniencji miejskiej. Często też informacje znajdujące się w inwentarzach trzeba uznać za niewystarczające czy wręcz mylące".

11 Jerzy Wyrozumski i Feliks Kiryk zostawili swoje uwagi na obwolutach rękopisów o sygnaturach 230a (obecnie: sygn. 29/121/0/-/111) i 230b (obecnie: sygn. 29/121/0/-/112) - Wyrozumski wyodrębnił jednostkę, której nadano sygnaturę 230aa (obecnie: sygn. 29/121/0/-/166), Kiryk zaś inny rękopis, który oznaczono jako 230bb (obecnie: sygn. 29/121/0/-/167), ANK, 29/121/0 Variae civitates et villae - zbiór szczątków zespołów 1340-1969... Zob. też uwagi na ten temat: J. Laberschek, Lelów, 
kim Kiryk, opracowując zarys dziejów tego miasta ${ }^{12}$. Część rękopisów zawierających księgi i fragmenty ksiąg miejskich Proszowic XVII i XVIII w. wykorzystał Franciszek Leśniak, w tekście dotyczącym nowożytnych dziejów miasta ${ }^{13}$. Z niektórych ksiąg miejskich Proszowic z XV i I połowy XVI w., w tym dwóch nieznanych autorom monografii tego miasta, korzystała Agnieszka Bartosze$w_{i c z}{ }^{14}$. W żadnym dotąd opracowaniu naukowym jednak nie zebrano i nie usystematyzowano informacji na temat zachowanych akt tego miasta. Nie będzie więc żadnej przesady w stwierdzeniu, że w zasadzie dotąd nie wiadomo, ile właściwie zachowało się ksiąg miejskich Proszowic i jaki zakres chronologiczny one obejmują. Nikt dotąd nie podjął się opisu wszystkich zachowanych akt miejskich Proszowic, czy nawet ich ogólnej charakterystyki, nie licząc bardzo ogólnych notatek w inwentarzach archiwalnych ${ }^{15}$. Do niedawna żaden z badaczy zajmujących się miastami w Polsce, jak też samymi Proszowicami, nie tylko nie opisał, ale nawet nie wymienił zachowanych ksiąg tego miasta ${ }^{16}$. Warto za-

[w:] Stownik historyczno-geograficzny województwa krakowskiego w średniowieczu, cz. 3, Kraków 1994, s. 510-512; K. Nabiałek, Fragment zaginionej ksiegi ławniczej miasta Lelowa z drugiej połowy XV wieku, [w:] Narodziny Rzeczypospolitej. Studia z dziejów średniowiecza i czasów wczesnonowożytnych, Kraków 2012, s. 1294-1295.

${ }_{12}$ F. Kiryk, Dzieje Proszowic w epoce piastowskiej i jagiellońskiej, „Rocznik Naukowo-Dydaktyczny Wyższej Szkoły Pedagogicznej w Krakowie. Prace Historyczne" 1967, z. 3, s. 21-49; idem, Miasto średniowieczne, [w:] Proszowice. Zarys dziejów do 1939 roku, red. F. Kiryk, Kraków 2000, s. 47-91. Zob. też: K. Grodziska, Zespót rękopisów średniowiecznych Biblioteki Naukowej PAU i PAN w Krakowie, [w:] Polska i jej sąsiedzi w późnym średniowieczu, red. K. Ożóg, S. Szczur, Kraków 2000, s. 400 .

${ }^{13}$ Autor cytuje księgi miejskie Proszowic znajdujące się w zbiorach PAU, nie podaje jednak opisu tych rękopisów. F. Leśniak, W okresie Polski szlacheckiej, [w:] Proszowice. Zarys dziejów do 1939 roku, red. F. Kiryk, Kraków 2000, s. 115-146 (passim, a zwłaszcza s. 142, gdzie krótka informacja o zachowanych księgach miejskich Proszowic z podaniem ich sygnatur). Ogólnie o znajdujących się w BPAU rachunkach i księgach miejskich z XVII i XVIII w., bez podania bliższych informacji i sygnatur tych rękopisów, wspomniał Kiryk (idem, Dzieje Proszowic..., s. 22, przypis 5).

${ }^{14}$ A. Bartoszewicz, Piśmienność mieszczańska..., s. 101; eadem, Urban literacy..., s. 15, 82, 117, $125,306,420$. Z kolei autorce nie była znana najstarsza księga tego miasta; nie cytowała też prac Kiryka dotyczących Proszowic; brak ich również w bibliografii. Najstarszą księgę miejską Proszowic wykorzystała badaczka ostatnio w opracowanym pod jej kierunkiem katalogu testamentów mieszczańskich (Testamenty z ksiag sadowych..., s. 14-15, 104).

${ }^{15}$ Noty inwentarzowe rękopisów miasta Proszowic są bardzo ogólne, a w wypadku dwóch najstarszych jednostek archiwalnych nie podano w nich nawet liczby stron. W literaturze w zasadzie brak informacji na temat budowy oraz zawartości zachowanych ksiąg miejskich Proszowic. Co istotne nie opisał tych rękopisów nawet Kiryk, który jako pierwszy wykorzystywał je naukowo (zob. przypis 12).

${ }_{16}$ Zajmujący się dziejami Proszowic Feliks Kiryk i Franciszek Leśniak poczynili na ten temat jedynie lakoniczne wzmianki (zob. przypis 13). Pierwszy z historyków znał i cytował w zasadzie tylko dwie najstarsze jednostki archiwalne (nie licząc księgi cechowej), drugi zaś wymienił tylko sygnatury rękopisów zawierających księgi miejskie. Obaj badacze nie wspominają nic o sześciu tomach ksiąg ławniczych Proszowic z XV i XVI w., a więc zapewne nie wiedzieli o ich istnieniu. 
uważyć, że Henryk Samsonowicz w sporządzonym w 1997 r. zestawieniu ksiąg sądowych małych miast $\mathrm{z}$ terenu Polski w ogóle nie uwzględnił Proszowic ${ }^{17}$.

Na niewielki stan wiedzy o wytworach kancelarii tego miasta zwrócono uwagę w związku z przygotowywaniem edycji rejestru przyjęć do prawa miejskiego. We wstępie do wydania sporządzono krótkie opisy trzech najstarszych ksiąg miejskich Proszowic, w których znajdowały się wpisy iuris civilis ${ }^{18}$. Okazało się, że jednak, że nawet przy opracowaniu wybranych tematycznie wpisów nie wszystkie zostały wówczas odnalezione i wydane ${ }^{19}$. Efekty kwerend przeprowadzonych w związku z edycją przekonują o potrzebie przygotowania odrębnego studium poświeconego zespołowi zachowanych ksiąg tego miasta, co jest celem niniejszego artykułu. Skoncentrowano się na klasyfikacji zachowanych ksiąg, datacji wpisów poszczególnych jednostek oraz na ich opisie zewnętrznym (kodykologicznym). Nie ma w tekście miejsca na sporządzenie wyczerpującego opisu zawartości tych rękopisów, co zresztą na obecnym etapie badań nie jest możliwe. Wymaga to gruntownych studiów, połączonych z opracowaniem ustroju i kancelarii tego miasta, które w przyszłości zostaną podjęte.

Dotychczasowa wiedza o najstarszych dziejach Proszowic, a w szczególności o ustroju tego miasta jest bardzo ogólna i wymaga pogłębionych badań ${ }^{20}$. Lokacja miasta nastąpiła w 1358 r. z inicjatywy Kazimierza Wielkiego. Powstało ono na bazie osady wiejskiej, która co najmniej do 1356 r. była własnością rycerską. Przed 1358 r. król został właścicielem wsi, ale nie wiadomo w jakich okolicznościach to nastąpiło. Nie zachował się przywilej lokacyjny, a na podstawie streszczenia z XVII w. nie sposób stwierdzić, jaką odmiankę prawa niemieckiego Proszowice pierwotnie uzyskały. Co najmniej od 1407 r., na mocy przywileju Władysława Jagiełły, stosowano tam prawo magdeburskie $^{21}$. Zgodnie z dokumentem lokacyjnym miasto zostało poddane zwierzchnictwu wójta i ławy. Według Kiryka nie doszło tam jednak nigdy do powołania urzędu wójta dziedzicznego, co jego zdaniem miało związek z włączeniem Proszowic do królewskich dóbr stołowych, podlegających wielkorządcy. We-

${ }^{17}$ H. Samsonowicz, op.cit., s. 478-479.

${ }^{18}$ K. Nabiałek, Registrum hominum ius civile susceptorum. Rejestr przyjęć do prawa miejskiego Proszowic z XV wieku, „Średniowiecze Polskie i Powszechne” 2018, t. 10(14), s. 148-151.

${ }^{19}$ Pominięty został jeden wpis w najstarszej księdze miejskiej oraz dwa, które znajdują się na kartach oddzielonych od tej księgi i przechowywanych w odrębnej jednostce archiwalnej. Ich edycja została przygotowana jako aneks do artykułu. Zob.: K. Nabiałek, Edycja rozproszonych wpisów rejestrów przyjęć do prawa miejskiego na przykładzie Proszowic i Sieradza, [w:] Editiones sine fine, t. 2, red. K. Kopiński, J. Tandecki, Toruń 2020 [w druku].

${ }^{20}$ Jedynym autorem, który zajmował się tą problematyką dla średniowiecza, jest Feliks Kiryk (idem, Dzieje Proszowic..., s. 21-49; idem, Miasto średniowieczne..., s. 47-91), ale ustalenia tego autora w odniesieniu do ustroju miasta są bardzo ogólne i wypada je nazwać raczej badaniami sondażowymi. Bardziej szczegółowo dla okresu nowożytnego sprawy ustrojowe Proszowic przedstawił w dwóch podrozdziałach (Zwierzchność, Władze miejskie) Franciszek Leśniak. Autor ten jednak skoncentrował się głównie na XVII-XVIII w. (idem, W okresie Polski szlacheckiej..., s. 113-150).

${ }^{21}$ F. Kiryk, Dzieje Proszowic..., s. 25-27; idem, Miasto średniowieczne..., s. 47-50. 
dług tego historyka występujący w źródłach od 1382 r. wójtowie proszowiccy byli najpewniej urzędnikami sądowymi, wybieranymi na kadencję spośród mieszczan $^{22}$. Można przypuszczać, że już od XIV w. wykształciła się ława sądowa, ale w źródłach ławnicy zostali poświadczeni dopiero w $1414 \mathrm{r}^{23}$ Pierwsza wzmianka o radzie pochodzi z $1403 \mathrm{r}^{24}$ Od XV do XVII w. rada składała się z czterech rajców, którzy kolejno w trakcie kadencji wymieniali się na urzędzie burmistrza. W tym okresie ławę sądową tworzyło siedmiu ławników oraz wójt sądowy ${ }^{25}$. Najstarszy fragment zachowanej księgi miejskiej, która zawiera przede wszystkim wpisy dokonane przed rajcami, zostały sporządzone 60 lat po lokacji, a zaledwie 15 lat od poświadczenia rady. Znacznie późniejsze są zachowane składki stanowiące dokumentację działalności sądu ławniczego, gdyż rozpoczynają się wpisami od 1449 r. Wolno przypuszczać, że akta te prowadzone były wcześniej, a ich brak jest tylko skutkiem zagubienia lub zniszczenia.

Opisując i klasyfikując księgi miejskie Proszowic, zastosowano klasyczny podział na księgi radzieckie i ławnicze, a także rachunkowe (związane z odrębnym urzędem miejskim), a ponadto dla XVIII w. wyodrębniono księgi sądu i urzędu łączonego (ławniczo-radzieckie), podobnie jak stosuje się to w większości opracowań dotyczących kancelarii miejskich ${ }^{26}$. Nie wydaje się adekwatny dla dokumentacji kancelaryjnej Proszowic zaproponowany niedawno przez Janusza Tandeckiego podział na trzy podstawowe grupy rzeczowe: ogólne księgi radzieckie, księgi administracyjno-finansowe i księgi sądowe ${ }^{27}$. W wypadku mniejszych ośrodków miejskich funkcję ksiąg sądowych mogły bowiem spełniać zarówno akta ławnicze, jak i radzieckie, gdyż zakres kompetencji tych instytucji nie był jasno i jednoznacznie określony. Ponadto tylko część ksiąg wpisów wytworzonych przez kancelarie miejskie można uznać za akta sądowe. Dlatego, wydaje się, że właściwym kryterium klasyfikacji jest rodzaj instytucji, której czynności dokumentowane są w danej księdze.

Doprecyzowania wymaga też samo pojęcie księgi miejskiej. Niedawno Marcin Grulkowski, opierając się na dotychczasowej literaturze i aktualnym stanie badań, wskazał komplet czterech cech, które winny spełniać księgi miejskie:

${ }^{22}$ Idem, Miasto średniowieczne..., s. 50-51.

${ }^{23}$ Ibidem, s. 50, autor twierdzi wprawdzie, że ławnicy zostali już poświadczeni w XIV w. Jest to jednak nieporozumienie, które wynika z błędnego datowania zapiski z księgi sądu wyższego na 1387 r. zamiast na 1417 r. ANK, 29/10/0 Sąd wyższy prawa niemieckiego na zamku krakowskim 1390-1794, seria 29/10/0/2.1, Akta (indukty) 1390-1641, sygn. 29/10/0/2.1/8 (dawne sygn. SWPM I-8, Teut. 1a), s. 33.

${ }^{24}$ F. Kiryk, Miasto średniowieczne..., s. 50-51.

${ }^{25}$ Ibidem, s. 50-51; F. Leśniak, W okresie Polski szlacheckiej..., s. 124-127.

26 J. Łosowski, op.cit., s. 75-109; M. Starzyński, Średniowieczny Kazimierz..., s. 51-102.

27 J. Tandecki, Dokumenty i kancelarie miejskie, [w:] Dyplomatyka staropolska, red. T. Jurek, Warszawa 2015, s. 424-434. 
forma kodeksu, budowa zewnętrzna w postaci kompleksu składek, urzędowy charakter treści, wpisy jako elementy budowy wewnętrznejej. ${ }^{28}$ W tym rozumieniu postać zewnętrzna, czyli wolumin posiadający oprawę, została postawiona na pierwszym miejscu. Grulkowski jednak wskazuje również na istnienie ksiąg miejskich w szerszym rozumieniu, tzw. strukturalno-genetycznym. Istotę takiej klasyfikacji, jego zdaniem, stanowi fakt założenia rękopisu, przeznaczenia w nim odpowiedniej ilości miejsca, stosowanie składek, a nie pojedynczych kart oraz zawartość, na którą składają się wpisy. Kluczowe znaczenie ma też zawartość treściowa, a raczej konstrukcja treściowa księgi, którą stanowią wpisy, a więc czynności kancelaryjno-urzędowe poświadczające zaistnienie nowej sytuacji prawnej $^{29}$. Do zestawu cech zaproponowanych przez badaczy dodać można jeszcze pierwotną intencję twórców, która nie zawsze doczekała się pełnej realizacji $\mathrm{w}$ postaci oprawionego kodeksu. $\mathrm{Z}$ taką sytuacją mamy do czynienia $\mathrm{w}$ odniesieniu do dwóch najstarszych jednostek aktowych Proszowic, zawierających dokumentację rady i ławy tego miasta, zachowanych w postaci zespołu składek bez oprawy. Nie ma wątpliwości, że rękopisy te należy uznać za księgi wpisów.

Księgi miejskie Proszowic zostały zestawione w porządku chronologicznym, poczynając od najstarszej z lat 1418-1456, a na fragmentach ksiąg z końca XVIII w. kończąc. W miarę możliwości została odtworzona struktura poszczególnych kodeksów. Ze względu na stan zachowania rękopisów nie zawsze była możliwa pełna rekonstrukcja danej jednostki aktowej. Dotyczy to zwłaszcza dwóch najstarszych ksiąg - miejskiej i ławniczej - zachowanych w postaci składek bez oprawy. W wypadku trzech rękopisów średniowiecznych zostały też opisane znaki wodne, wraz z informacjami o zidentyfikowaniu podobnych lub tożsamych filigranów w publikowanych katalogach (w tym w bazach internetowych). Zestawienie znaków, które zachowały się na papierze $\mathrm{z}$ datowanymi wpisami wraz z podaniem ich wymiarów może być przydatne w badaniach kodykologicznych. Szczególną trudność w identyfikacji i opisie sprawiają luźne fragmenty ksiąg z XVII i XVIII w. oraz grupa składek najstarszej księgi miejskiej z lat 1418-1456.

\section{Zachowane księgi miejskie Proszowic}

\section{Księga miejska Proszowic z lat 1418-1456}

Za najstarszą zachowaną księgę miejską Proszowic, a w zasadzie jej fragment, należy uznać zespół składek i luźnych kart, zawierających głównie wpisy rady, a w mniejszym stopniu też wójta wraz z rajcami i ławnikami, z lat 1418-1456, przechowywany w ANK (Oddział III) w zespole Variae civitates et

${ }^{28}$ M. Grulkowski, Definicja i klasyfikacja ksiag miejskich. Księgi w kancelariach miast obszaru Hanzy, [w:] Nauki pomocnicze historii. Teoria, metody badań, dydaktyka, red. A. Jaworska, R. Jop, Warszawa 2013, s. 124-125.

${ }^{29}$ Ibidem, s. 123-124, 128-130. 
villae (nr 29/121/0) jako jednostka archiwalna oznaczona sygnaturą 166 (dawna sygn. IT 230aa) ${ }^{30}$. Jest to rękopis papierowy bez oprawy, zapakowany w papierową obwolutę $\mathrm{z}$ notami archiwalnymi ${ }^{31}$, złożony z luźnych składek oraz pojedynczych kart o wymiarach 10,4-11 x 30,5-31,6 cm (format dutki). Rękopis ma paginację ołówkową z II połowy XX w., według której miał liczyć 236 stron, jednak w wyniku błędu przy numeracji pominięto jedną kartę po stronie 192, którą później oznaczono jako strony 192A i 192B. Dlatego w rzeczywistości stron jest 238 .

Obecny układ kart z pewnością nie odpowiada ich pierwotnemu porządkowi chronologicznemu. Na początku umieszczono dwie luźne karty (s. 1-4), na których znajdują się najstarsze datowane wpisy (1. 1418-1419). Po nich następują dwie składki liczące 8 i 4 kart (4+4: s. 5-20 i 2+2: s. 21-28), a następnie znów dwie luźne karty (s. 29-30 i 31-32) z wpisami z lat 1426-1427, które powinny być umieszczone wcześniej, po składce pierwszej. Później jest trzecia składka licząca 12 kart (6+6: s. 33-56), a po niej luźna karta (s. 57-58) z wpisami z 1433 r. (z kawałkiem drugiej brakującej karty, szerokości ok. $1 \mathrm{~cm}$, ze śladem po szyciu, co dowodzi, że wcześniej była to część składki). W dalszej kolejności jest dziewięć składek zbudowanych z różnej liczby kart: składka czwarta - z 12 (6+6: s. 59-82), piąta - z 12 (6+6: s. 83-106), szósta - z 12 (s. 107-130), siódma z 12 (6+6: s. 131-154), ósma - z 8 (4+4: s. 155-170), dziewiąta - z 4 (2+2: s. 171-178), dziesiąta - z 8 (4+4: s. 179-192B, przy czym w składce są dodatkowo dwie strony po stronie 192 oznaczone jako 192A i 192B), jedenasta - z 4 (2+2: s. 193-200), dwunasta - z 8 (4+4: s. 201-216). Po nich znów umieszczono luźną kartę (s. 217-218) z wpisami z 1451 r., sporządzonymi ręką, która zapisała tak ostatnią stronę dwunastej składki (s. 216), jak i następną (s. 219), która rozpoczyna ostatnią - trzynastą składkę złożoną z 6 kart (3+3: s. 219-230), co przekonuje o jej właściwym umiejscowieniu. Na stronach 217-218 znajduje się fragment znaku wodnego, który odpowiada drugiej jego części na luźnej karcie (s. 231-232, zapisana tą samą ręką co s. 230) z datowanym wpisem z $1454 \mathrm{r}$. (na s. 232, a po nim na samym dole tej strony $z$ wpisem do prawa miejskiego z 1456 r.). Należy uznać, że obie karty tworzyły całość (bifolium) i stanowiły zewnętrzną część składki trzynastej, która liczyła zatem pierwotnie osiem kart (4+4: s. 217-232). Na końcu rękopisu umieszczono niewątpliwie niewłaściwie bifolium (s. 233-236), zawierające wpisy z roku 1431 i 1434.

Jednostka składa się zatem obecnie z 13 składek o różnej liczbie kart (od 4 do 12) oraz dodatkowo ośmiu luźnych kart, w tym jednego bifolium. Nie

${ }^{30}$ Wcześniej rękopis wchodził w skład sygn. IT 230a (w zespole Variae civitates et villae), obejmującej składki ksiąg lelowskich, ale dzięki ekspertyzie Jerzego Wyrozumskiego został z niej wyjęty (zob. przypis 11).

${ }^{31}$ Na papierowej obwolucie wpisano ołówkiem ręką z XX w.: „,wyjęte z IT 230a”; poniżej nota-uwaga zapewne Wyrozumskiego: „Księga sądowa m. Proszowic w. XV 1418.1454. Mylnie włożona w księgę lelowską” [z dopiskiem:] „(Uwaga dra Jerzego Wyrozumskiego)”. 
ulega wątpliwości, że jest to tylko część akt miejskich z lat 1418-1456, zachowanych i zestawionych zapewne dość przypadkowo. Przekonują o tym dalsze cztery karty niewątpliwie wytworzone wspólnie z pozostałymi składkami, znajdujące się w innej jednostce archiwalnej zawierającej luźne materiały dotyczące Proszowic (w przeważającej mierze dokumenty miejskie i ekstrakty z ksiąg miejskich z XVII i XVIII w. $)^{32}$. Owe cztery karty stanowią najprawdopodobniej fragment składki lub składek tej samej księgi. Zawierają wpisy spraw załatwianych przed rajcami Proszowic (także na sądzie gajonym). Są to dwa bifolia, obecnie złożone razem, ale być może wtórnie, $\mathrm{z}$ wyraźnymi ściegami w środku każdego z nich, o wymiarach kart 11 x 32,2 cm. Karty mają paginację ołówkową wprowadzoną w obrębie całej jednostki archiwalnej (s. 351-358) ${ }^{33}$. Na papierze bifolium oznaczonego jako strony 353-356 znajduje się znak wodny. Wątpliwości co do uszeregowaniu kart w obecnym układzie wzbudzają zachowane w środku każdego bifolium nici, które zdają się wskazywać, że mogły to być środkowe części dwóch różnych składek. Za ułożeniem tych czterech kart łącznie przemawia jednak chronologia wpisów - strony 351-352: 1435 r.; strony 353-356: 1436 r. (do 9 maja); strona 357: 1436 r. (17 lipca); strona 358: 1438 i 1439 r.

Na papierze księgi stwierdzono co najmniej 11 różnych znaków wodnych:

1. Głowa wołu z gwiazdą sześciopromienną na pojedynczym pręcie między rogami, o wymiarach: 86 x $33 \mathrm{~mm}$ (s. 1-2, 13-14, 17-18, 23-24, 39-40, 43-44, 53-54, 233-236 oraz w rękopisie o sygn. 281, s. 355356).

2. Głowa wołu $\mathrm{z}$ różą siedmiolistną na pręcie podwójnym między rogami, o wymiarach 117 x $33 \mathrm{~mm}$ (s. 61-62, 63-64, 69-70).

3. Kiść winogron o wymiarach 55 x 34 mm (s. 85-86 i 103-104, 87-88 i 101-102, 89-90 i 99-100).

4. Głowa wołu z różą siedmiolistną na pręcie podwójnym między rogami, o wymiarach 122 x 36 mm (s. 131-132, 139-140, 147-148).

5. Głowa wołu z różą siedmiolistną na pręcie podwójnym między rogami, o wymiarach 103 x 34 mm (s. 159-160 i 165-166, 155-156 i 169-170, 171-172).

6. Głowa wołu z różą sześciolistną na pręcie podwójnym między rogami, o wymiarach 115 x 34 mm (s. 189-190, 192A-192B).

${ }^{32}$ Rękopis jest przechowywany w ANK, 29/121/0/ Variae civitates..., sygn. 29/121/0-/281 (dawna sygn. IT 277).

${ }_{33}$ Ibidem. Karty te w ramach jednostki archiwalnej zostały wyodrębnione w osobną obwolutę, na której znajduje się notatka sporządzona przez Feliksa Kiryka w 1965 r.: „Proszowice 1435-1439 Consularia. Proszowice (na pewno jest to fragment ks. sąd. miasta, która znajduje się w tym archiwum wpięta w księgę lelowską - patrz IT - pod Lelów”. Jednak w publikacjach dotyczących Proszowic Kiryk nie wspomina o tym zidentyfikowanym przez siebie fragmencie księgi. 
7. Głowa wołu z wysokim krzyżem na pręcie podwójnym między rogami, o wymiarach 117 x 40 mm (s. 109-110, 115-116, 125-126).

8. Głowa wołu z wysokim krzyżem na pręcie podwójnym między rogami, z poprzeczną belką pod krzyżem, o wymiarach 95 x 30 mm (s. 193-194 i 199-200).

9. Potrójna góra (Dreiberg), o wymiarach 28 x 24 mm (s. 207-210).

Ponadto dwa bardzo słabo czytelne znaki:

10. Głowa wołu z kwiatem na pręcie podwójnym między rogami, o długości około $105 \mathrm{~mm}$ - uszkodzony (s. 215-216).

11. Głowa wołu $\mathrm{z}$ różą na pręcie podwójnym między rogami, o wymiarach około 110 x $34 \mathrm{~mm}$ - słabo czytelny (s. 217-218 i 231-232, 227-228).

Udało się znaleźć podobne lub identyczne znaki w katalogach filigranów dla: nr 1 (Biecz - 1416 r.) $)^{34}$, nr 2 (Kraków - 1429 r.) $)^{35}$, nr 3 (Sion - 1448 r. lub Heidelberg - 1454/1455 r.) ${ }^{36}$, nr 4 (Kraków - 1445 r.) ${ }^{37}$ oraz nr 9 (Würzburg - 1449 r., Villingen -1448 r.) ${ }^{38}$. Datowanie tych znaków odpowiada datacji wpisów i zgadza się z czasem produkcji papieru, który mógł być używany w kancelarii miejskiej jeszcze przez kilka do kilkunastu lat po jego zakupieniu.

Zawartość wpisów umieszczonych na luźnych kartach (zwłaszcza ich datacja) oraz porównanie rąk pisarzy pozwala na stwierdzenie, że część z nich jest umieszczona niewłaściwie. Dotyczy to przede wszystkim składek: drugiej (obecne s. 21-28) i trzeciej (obecne s. 33-56) oraz trzech luźnych kart (obecne s. 29-30, 31-32, 57-58) i bifolium umieszczonego na końcu jednostki (obecne s. 233-236). Karty składki drugiej zostały złożone wtórnie, w niewłaściwym porządku i niewątpliwie niezgodnie z intencją kancelarii miejskiej (początek to s. 25-28). Ponadto w obrębie kart tej składki powinny się znaleźć również karty składki trzeciej, a także wspomniane już luźne karty i bifolium. Do środka składki powinna być przemieszczona pierwsza część podwójnej karty (s. 233-234), o czym przekonują zarówno daty, ręka pisarza (ta sam na s. 28 i s. 233, kontynuująca wpisy do prawa niemieckiego), jak i znak wodny (nr 1 - ten sam w składce drugiej i na karcie oznaczonej s. 233-234), a po niej kolejno wstawione winny być dwie luźne karty, zawierające wpisy z lat 1426 (s. 29-30) i 1426-1427 (s. 31-32). Po nich winna być umieszczona cała obecna składka trzecia (s. 33-56 z wpisami z 1433 r.), a dopiero po niej karta oznaczona jako strony 57-58, a przy tym zapewne

${ }^{34}$ F. Piekosiński, Średniowieczne znaki wodne zebrane z rękopisów przechowywanych $w$ archiwach i bibliotekach polskich, głównie krakowskich, wiek XIV, Kraków 1893, nr 814.

${ }^{35}$ Ibidem, nr 988.

${ }^{36}$ C.M. Briquet, Les Filigranes dictionnaire historique des marques du papier des leur apparation vers 1282 jusqu en 1600, t. 4, Paris-Genève 1907, nr 12997, https://www.wzma.at [dostęp: 01.02.2018], nr 4000-424_36.

37 Ibidem, nr 894.

${ }^{38}$ Baza internetowa: www.piccard-online.de [dostęp: 01.02.2018], nr 150060, 150088. 
odwrotnie, tj. najpierw strona 58, a potem strona 57, na co wskazuje chronologia wpisów ${ }^{39}$. Dalej powinna znaleźć się druga część podwójnej karty (s. 235-236), a na końcu wreszcie odwrócone karty składki drugiej - kolejno strony 21-24. Dodać należy, że po tak zrekonstruowanej składce powinno się umieścić cztery karty przechowywane osobno w rękopisie o sygnaturze 281, zawierające wpisy z lat 1435-1436 i 1438-1439.

Właściwy układ kart rękopisu o sygnaturze 166 prawdopodobnie powinien być zatem następujący: strony 1-20, 25-28, 233-234, 29-30, 31-32, 33-56, 58-57, 235-236, 21-24, cztery karty z sygn. 281 (obecnie oznaczone tam jako s. 351-358), 59-192, 192A-192B, 193-232.

Trzeba jednak wyraźnie podkreślić, że jest to nadal rekonstrukcja hipotetyczna, a dalsze szczegółowe badania nad zawartością wszystkich wpisów oraz ogólnie nad kancelarią miasta Proszowic może spowodować pewne korekty ${ }^{40}$. Ze względu na treść akt, w których znajdują się obok zdecydowanie przeważających wpisów dokumentujących działalność rady także wpisy wójta i ławników (w tym również dokonane na sądach gajonych), brak możliwości jednoznacznego sklasyfikowania tego rękopisu. Stąd najlepiej określać go mianem księga miejska. Takie nazewnictwo jest zresztą w pełni zgodne $\mathrm{z}$ terminologią stosowaną w samym źródle, w którym dokumentację prowadzoną przez rajców określano kilkukrotnie jako liber civilis $^{41}$.

Najstarszy wpis w księdze jest datowany na: 8 marca 1418 r. (s. 1), najpóźniejszy zaś na 7 lutego 1456 r. (s. 232). W obrębie tych skrajnych dat znajdują się wpisy z następujących lat: 1418-1425, 1427-1435, 1439-1456. Po uwzględnieniu kart z rękopisu 281 możemy uzupełnić akta dla lat 1435-1436 i roku 1438. Brak więc wpisów z 1426 r. i lat 1435-1437, a w zasadzie też z 1438 r. (nie licząc trzech drobnych wpisów rachunkowych), co dowodzi, że dysponujemy tylko częścią dokumentacji kancelarii miasta Proszowic z tego okresu.

\section{Księga lawnicza $\mathrm{z}$ lat (1450?) 1451-1509 $\mathrm{z}$ fragmentami $\mathrm{z}$ lat 1449-1450}

Drugą chronologicznie zachowaną księgą miejską Proszowic są akta ławnicze przechowywane w ANK w zespole Variae civitates et villae ( $\mathrm{nr}$ 29/121/0), obecnie oznaczone sygnaturą 167 (dawna sygn. IT 230bb) ${ }^{42}$. Jest to rękopis papierowy bez oprawy (umieszony luźno w tekturowej okładce zapewne

\footnotetext{
${ }^{39} \mathrm{Na}$ stronie 57 - trzy zapiski z $1433 \mathrm{r}$. bez daty dziennej, a czwarta: die dominico proximo ante Natale Domini (20 XII) z 1433 r.; na stronie 58 - dwie zapiski z 1433 r. z datami dziennymi: feria secunda infra octavas Visitacionis Marie (3 VII), die dominico in die sancti Francisci (4 X).

${ }^{40}$ Zaproponowana rekonstrukcja, po wstępnych oględzinach rękopisu okazała się częściowo nieścisła (zob.: K. Nabiałek, Registrum hominum..., s. 149).

${ }^{41}$ ANK, 29/121/0 Variae..., sygn. 29/121/0/-/166, s. 34, 41, 42, 138, 155; m.in. w 1431 r. zapisano: circa eundem librum civilem coram dominis consulibus (ibidem, s. 42).

${ }^{42}$ Wcześniej rękopis wchodził w skład sygn. IT 230b (w zespole Variae civitates et villae) wraz z fragmentem ksiąg ławniczych Lelowa oraz innymi nieuporządkowanymi materiałami. Został z niej wyjęty dzięki ekspertyzie Kiryka (zob. przypis 11).
} 
z XX w. ${ }^{43}$, a ponadto $\mathrm{w}$ papierowej obwolucie ${ }^{44}$ ), złożony z luźnych składek oraz pojedynczych kart o wymiarach 10,3-11,1 x 31,4-32,3 cm (format dutki). Rękopis ma paginację ołówkową z II połowy XX w., według której miał liczyć 630 stron, jednak w wyniku błędu przy numeracji pominięto w sumie 10 stron: dwie po s. 236 , dwie po s. 238 , dwie po s. 368 , dwie po s. 376 , dwie po s. 474 i dwie po s. 475. Pominięte strony (z wyjątkiem powtórzonej s. 274) nie zostały spaginowane. Dlatego w rzeczywistości stron jest 640. Pod względem zawartości są to wpisy dokumentujące działalność sądu ławniczego (wójtowsko-ławniczego) miasta Proszowic z lat 1450?, 1451-1452 (s. 1-100), 1454 (s. 101-112), 1481-1486 (s. 113-204), 1488-1509 (s. 205-630). Najstarsze datowane wpisy pochodzą z 8 stycznia 1451 r. (s. 1). Ponieważ przed nagłówkiem sądu gajonego $\mathrm{z}$ tej daty znajdują się jeszcze dwa wpisy, teoretycznie mogły być sporządzone w sesji sądu z końca $1450 \mathrm{r}$. Nie jest to jednak pewne ${ }^{45}$. Ostatnie dwa wpisy są pod datą sądu gajonego z 28 września 1509 r. (s. 630). Podobnie jak rękopis najstarszy (sygn. 166), również tę jednostkę można uznać za księgę wpisów w rozumieniu strukturalno-genetycznym.

Księga jest niekompletna i zawiera tylko część składek z tego okresu działalności sądu ławniczego o czym świadczą duże luki chronologiczne wpisów. Obok pełnych składek są też luźne karty - pojedyncze i podwójne. Układ kart ustalony przy porządkowaniu rękopisu i paginacji odpowiada porządkowi chronologicznemu z jednym wyjątkiem - jedna składka zawierająca wpisy za $1483 \mathrm{r}$. jest umieszczona za wcześnie - w ciągu chronologicznym składek za rok 1482. Dlatego po stronie 148 powinny być strony $165-180$, po nich zaś dopiero strony 149-164, a następnie ciąg dalszy od strony 181 .

Obecnie na początku jednostki jest pięć kolejnych składek o różnej liczbie kart - kolejno: 4 (s. 1-8), 18 (9-44), 8 (s. 45-60), 8 (s. 61-76) i 12 (s. 77-100). Następnie umieszczona jest luźna karta (s. 101-102) - uszkodzona mocno na dole i górze i na pewno oderwana od nieznanej składki, a po niej dwa bifolia złożone razem (s. 103-110), ale raczej nie tworzące składki, bo brak śladów po

\footnotetext{
${ }^{43} \mathrm{Na}$ obwolucie u góry nalepka z drukowanym napisem: „Archiwum Akt Dawnych Krakowa” i wpisaną zielonym atramentem sygnaturą: „I.T. 230bb” (druga litera dopisana innym atramentem); na grzbiecie obwoluty tym samym atramentem wpisany nr: „80”.

${ }^{44}$ Na papierowej obwolucie nota: „IT 230bb” i poniżej, zapewne ręką Kiryka: „Księga radziecka miasta Proszowic z drugiej połowy [skreślone: „XV i z pierwszej połowy XVI w.”] 1451-1512”; poniżej tą samą rękąa: „W katalogu mylnie informacje [s] sygnatura o Lelowie!”; poniżej: „Uwaga Feliksa Kiryka, 12. 9. 68 [nieczytelny podpis]".

${ }^{45}$ Nagłówek sądu: Iudicium particulare est bannitum feria VIta infra octavas Epiphanie [...] anno Domini Mo CCCCo LIo (ANK, 29/121/0 Variae..., sygn. 29/121/0/-/167, s. 1). Pierwszy zwykły sąd gajony w roku był w Proszowicach najczęściej sprawowany w najbliższy piątek po święcie Objawienia Pańskiego, co było zresztą zgodne z zaleceniami prawa magdeburskiego i powszechnie przyjętą praktyką w miastach polskich. Nie można jednak wykluczyć, że w $1451 \mathrm{r}$. przed 8 stycznia był sprawowany sąd potrzebny, jak np. w 1493 r., kiedy zwołano go w sam dzień Trzech Króli (ibidem, s. 291).
} 
przeszyciu kart, po czym następują dwie uszkodzone luźne karty (s. 111-112, 113-114). Dalej jest szósta składka licząca 6 kart (s. 115-126) a po niej znów jedna luźna karta (s. 127-128), po której następuje sześć kolejnych składek - od 7 do 12 - o różnej liczbie kart, odpowiednio: 10 (s. 129-148), 8 (s. 149-164), 8 (s. 165-180), 4 (s. 181-188), 8 (s. 189-204), 4 (s. 205-212). Po składce 12 są dwa osobne bifolia (s. 213-216 i 217-220), a po nich 21 kolejnych składek od 13 do 33, o różnej liczbie kart - odpowiednio: 4 (s. 221-228), 8 (s. 229-240), 8 (s. 241-256), 8 (257-272), 10 (273-292), 10 (s. 293-312), 10 (s. 313-332), 8 (s. 333-348), 8 (s. 349-364), 6 (s. 365-374 w tym dwie pominięte strony po s. 368), 12 (s. 375-396 w tym dwie pominięte strony po s. 376), 8 (s. 397-412), 4 (s. 413-420), 8 (s. 421-436), 8 (s. 437-452), 8 (s. 453-468), 8 (s. 469-482 w tym dwie pominięte strony - jedna po s. 474 i jedna po s. 475), 8 (s. 483-498), 4 (s. 499-506), 8 (s. 507-522), 8 (s. 523-538). Część składek jest ze sobą połączona nicią (składki 19 i 20, 25 i 26). Po składce 33 umieszczono bifolium (s. 539-542), które zostało wyjęte z nieznanej składki, na co wskazują dziurki po ściegu, a po nim kolejna luźna podwójna karta (s. 543-546), ale bez śladów nici. Wreszcie na końcu jednostki umieszczono pięć składek połączonych ze sobą nicią od dołu - składki 34 do 38, o liczbie kart - odpowiednio: 6 (s. 547-558), 8 (s. 559-574), 8 (s. 575-590), 12 (s. 591-614), 8 (s. 615-630).

Rękopis składa się więc z 38 składek oraz 14 luźnych kart, w tym pięciu kart podwójnych.

Na papierze składek i luźnych kartach stwierdzono prawdopodobnie 16 różnych znaków wodnych:

1. Wieża, o wymiarach 54 x 30 mm (s. 1-2, 5-6, 17-18, 21-22, 77-78 i 99 $100,85-86$ i $91-92$ ).

2. Głowa wołu z krzyżem i z różą siedmiolistną na pręcie podwójnym między rogami, o wymiarach: 125 x $40 \mathrm{~mm}$ (s. 55-56, 57-58, 65-66, 75-76).

3. Głowa wołu $\mathrm{z}$ różą sześciolistną i krzyżem nad różą na podwójnym pręcie między rogami, o wymiarach: $122 \mathrm{~mm}$ x $38 \mathrm{~mm}$ (s. 109-110, 113-114).

4. Głowa wołu z krzyżem na podwójnym pręcie, oplecionym przez węża, o wymiarach: 181 x $50 \mathrm{~mm}$ (s. 117-118, 123-124, 141-142, 145-146, 153-154, 159-160, 183-186, 207-208, 233-234 i 237-238, 259-260, 261-262, 281-282, 285-286, 297-298 i 307-308, 311-312, 313-314 i $331-332,317-318$ i $327-328,325-326,355-356,357-358,367-368$, 373-374, 383-386, 391-392, 393-394, 399-400 i 409-410, 403-406, 423-424 i 427-428, 471-472 i 481-482, 473-474 i 479-480, 485-486).

5. Głowa wołu z krzyżem na podwójnym pręcie, oplecionym przez węża, o wymiarach: 172 x $40 \mathrm{~mm}$ (s. 341-342, 347-348).

6. Głowa wołu z krzyżem oplecionym przez węża na podwójnym pręcie, nad nim gwiazda sześciopromienna, o wymiarach: 172 x 40 mm (s. 149-150).

7. Korona zamknięta $\mathrm{z}$ krzyżem na pręcie podwójnym, o wymiarach: 141 x 40 mm (s. 167-168, 173-174, 417-418). 
8. Głowa wołu z koroną na pręcie podwójnym, o wymiarach: 113 x $39 \mathrm{~mm}$ (s. 189-190 i 203-204, 193-194 i 199-200).

9. Korona zamknięta, o wymiarach: 124 x $47 \mathrm{~mm}$ (karta nieliczbowana przed s. 239).

10. Głowa wołu z różą pięciolistną na pręcie podwójnym między rogami i z grotem na pręcie pojedynczym w dół, o wymiarach: 159 x $48 \mathrm{~mm}$ (s. 213-216, 221-222 i 227-228).

11. Głowa wołu z różą pięciolistną na pręcie podwójnym między rogami i z grotem na pręcie pojedynczym w dół, o wymiarach: 162 × $52 \mathrm{~mm}$ (s. 453-454, 459-460 i 461-462).

12. Dzban, o wymiarach 52 x 42 mm (s. 243-244 i 253-254, 247-250).

13. Korona zamknięta $\mathrm{z}$ krzyżem na pręcie podwójnym, o wymiarach: 51 x $39 \mathrm{~mm}$ (s. 447-448 i 451-452).

14. Korona zamknięta z krzyżem na pręcie podwójnym, o wymiarach: 134 x 53 mm (s. 487-488 i 493-494, 509-510 oraz 511-512 i 517-519).

15. Kula $\mathrm{z}$ gwiazdą sześciopromienną na pręcie pojedynczym, o wymiarach: 77 x $32 \mathrm{~mm}$ (s. 499-500).

16. Popiersie dziewczyny w czepku na głowie: składka 38 (s. 627-628).

Spośród tych filigranów udało się odnaleźć w katalogach podobne dla: nr 1 (Ansbach, Monachium, Torun - 1. 1448-1453) ${ }^{46}$, nr 2 (Kraków - 1452 r.) ${ }^{47}, \mathrm{nr} 3$ $(\text { Kraków }-1467 \text { r. })^{48}$, nr 9 (Rot, Kloster - 1489 r. $)^{49}$, nr 10 (Ellwangen - 1. 1494$1495)^{50}$. We wszystkich tych przypadkach przybliżony czas powstania papieru, który wykorzystano do sporządzenia akt ławniczych, odpowiada datacji wpisów.

Rękopis jest niekompletny i zawiera tylko część składek z działalności sądu ławniczego w latach 1451-1488, o czym świadczą duże luki chronologiczne. Jedna brakująca składka (2+2), obejmująca wpisy od 4 lipca do 21 października 1485 r., niewątpliwie została omyłkowo wszyta do równolegle prowadzonej księgi ławniczej (sygn. 160, s. 381-388 - jako składka 24). Powinna ona znajdować się w rękopisie 167 między składkami 10 (kończącą się na s. 188) a składką 11 (od s. 189). Przekonuje o tym datacja wpisów zarówno w rękopisie 167, jak i w 160. W tym pierwszym po sesji sądu 10 czerwca 1485 r. (s. 188), następna składka rozpoczyna się od 4 listopada 1485 (s. 189). Z kolei w rękopisie 160 wszystkie daty sądów ze stron 381-388 powtarzają się na stronach 343-351. Przemieszczenie składki nastąpiło jeszcze na początku XVI w., przy wykonywaniu oprawy. Być

${ }^{46}$ Der Wasserzeichenkartei Piccard im Huptsaatsarchiv Stuttgart, bearbaitet von G. Piccard, t. 3. Die Turmwasserzeichen, Stuttgart 1970, nr 324. Wydaje się, że identyczny - o tych samych wymiarach - znajduje się w rękopisie z Biblioteki Uniwersytetu w Monachium datowany na 1456 r. (https:// www.piccard-online.de/ergebnis1.php [dostęp: 01.02.2018], nr 100639).

${ }^{47}$ F. Piekosiński, op.cit., nr 1056

48 Ibidem, nr 1045.

${ }^{49}$ Baza internetowa: www.piccard-online.de [dostęp: 01.02.2018], nr 53045.

${ }^{50}$ Ibidem, nr 66069-66070. 
może powodem pomylenia składek były podobne znaki wodne znajdujące się na papierze tej składki (24), jak też z nią sąsiadujących (22-23, 25-28) ${ }^{51}$.

Dowodzi tego również fragment akt ławniczych, zachowany w rękopisie BPAU o sygnaturze 440, złożony z siedmiu kart, zawierający wpisy z $1449 \mathrm{r}$. i z jednej sesji z $1450 \mathrm{r}^{52} \mathrm{~W}$ prawdzie obecny układ kart nie pozwala na pewne stwierdzenie, jakie było ich pierwotne wzajemne położenie w składce lub zespole składek, ale nie ulega wątpliwości ich związek formalny z omawianą księga ławniczą. Przekonuje o tym format kart, układ graficzny, zawartość oraz żywa pagina umieszczona u góry kart na stronie verso (XLIXo). Można hipotetycznie założyć, że karty te mogły stanowić wspólną składkę, czy raczej część składki (nieparzysta liczba kart -7 ). Karty są paginowane w ramach całej sygnatury rękopiśmiennej (k. 115-121); trzy karty są luźne (k. 115, 120, 121), a pozostałe to dwa bifolia (k. 116-117, 118-119). Na dwóch kartach znajdują się znaki wodne - na karcie 119 (głowa wołu z różą siedmiolistną na pręcie podwójnym) i na karcie 121 (korona - fragment, druga część była na oderwanej karcie; prawdopodobnie identyczny znak jak w księdze o sygn. 166 na s. 207-210 - znak nr 9). Na kratach tych znajdują się wpisy z sądów ławniczych gajonych z 1449 r. (7 marca - 5 grudnia) i z 1450 r. (9 stycznia). Ten fragment akt ławniczych Proszowic, pomimo oddzielnego przechowywania, powinien być opisywany łącznie z rękopisem o sygnaturze 167 i traktowany jako jego najstarsza odnaleziona część.

Za fragment akt ławniczych należy uznać również dwie niepaginowane karty (bifolium) znajdujące się w innej jednostce archiwalnej z ANK z zespołu Variae civitates et villae ( $\mathrm{nr}$ 29/121), oznaczonej sygnaturą 112 (dawna sygn. IT 230b), w której zasadniczo znajdują się fragmenty ksiąg miejskich Lelowa. Karty papierowe o wymiarach 11 x 33,1 cm znajdują się w tej jednostce wśród innych fragmentów rękopisów umieszczonych w obwolucie z napisem „Mieszanka”. Stanowiły one wcześniej część środkową składki księgi, o czym świadczą zachowane nici po ściegach. Znajduje się na nich znak wodny: głowa wołu z krzyżem na podwójnym pręcie oplecionym przez węża, ale jest to inny typ niż na papierze z pozostałych ksiąg miejskich. $Z$ treści wpisów wynika, że jest to fragment księgi ławniczej Proszowic z czterech różnych sesji sądu gajonego z października i listopada nieznanego roku (w datacjach sądu brak roku). Na podstawie pisma można przyjąć, że tekst powstał w ostatniej ćwierci XV w. Prawdopodobnie jest to fragment jednej z zaginionych składek rękopisu o sygnaturze $167 \mathrm{z}$ lat 70 . bądź 80. (może 1487 r.) tego stulecia.

Być może również z tą księgą należy łączyć składkę papierową znajdującą się w ANK w rękopisie oznaczonym obecnie 281, zawierającą wpis jednej sprawy dokonanej przed sądem ławniczym proszowickim, bez podanej daty

\footnotetext{
${ }^{51}$ Zob. znaki wodne nr 18 i $20 \mathrm{w}$ opisie rękopisu 160.

${ }^{52} \mathrm{Na}$ ten fragment księgi miejskiej Proszowic zwrócił uwagę Feliks Kiryk (idem, Dzieje Proszowic..., s. 22).
} 
rocznej (feria tertia ante Epifaniam); była to sprawa nietypowa, bo dotyczyła zatargu kmiecia z Rzezawy z mieszczaninem proszowickim. Jest to składka złożona z czterech kart $(2+2)$ o wymiarach $10,7-11$ x 32,1-32,2 cm, z wyraźnymi ściegami w środku. Karty w składce nie są paginowane. Zapisane są tylko dwie pierwsze karty, a dwie pozostałe są czyste. Na papierze składki znajduje się znak wodny (na k. $1 \mathrm{i}$ 4) przedstawiający głowę wołu z różą pięciolistną na pręcie pojedynczym $\mathrm{z}$ grotem na pręcie pojedynczym w dól, który jest podobny albo nawet identyczny jak znak nr $10 \mathrm{w}$ rękopisie o sygnaturze 167, a w katalogu filigranów datowany na lata 1494-1495. Tę składkę akt ławniczych Proszowic należałoby więc w przybliżeniu datować na schyłek XV w., za czym przemawia również wygląd pisma.

\section{Księga lawnicza z lat 1474-1511}

Trzecią chronologicznie księgą miejską Proszowic i jedyną z okresu średniowiecza, zachowaną w postaci kodeksu, jest rękopis ANK z zespołu Variae civitates et villae (nr 29/121/0), oznaczony sygnaturą 160 (dawna sygn. Prosz. 1). Jest to kodeks papierowy $\mathrm{w}$ formacie dutki o wymiarach kart $11,2 \times 32,6$, oprawiony w pergamin typu południowego, garbowany i bielony jednostronnie, na zewnątrz zżółkły, a wewnątrz ściemniały i pobrudzony. Okładka w dolnej części jest złożona na dwie części, a na krawędzi części zagiętej znajdują się dwie okrągłe dziurki, co świadczy o tym, że wcześniej blok kodeksu był zamykany i zawiązywany z góry na dół. Na zewnątrz grzbietu są widoczne trzy zwięzy. $Z$ przodu górnej okładki wpisano ołówkiem dużym pismem liczbę 1, a na wewnętrznej stronie u góry zamieszczono notę stylizowaną na nagłówek, sporządzoną przez pisarza, poświadczającą założenie przez niego księgi 6 maja 1474 r.: anno domini M CCCC LXX IIIIo per me Nicolaum de Wresnya artium baccalarium presens liber cepit [!] [...] feria sexta ante Stanislaum in vere. Data ta powtarza się w nagłówku sądu gajonego, wpisanej na początku pierwszej strony rękopisu. Pergamin stanowiący okładkę po stronie wewnętrznej niemal na całej powierzchni jest zapisany. Zdecydowaną większość odczytanych not stanowią wpisy poświadczające przyjęcie osób do prawa miejskiego ${ }^{53}$. Okładkę wykonano najpewniej równocześnie z założeniem księgi, a więc w 1474 r., ale najprawdopodobniej służyła początkowo jako luźna obwoluta, karty zaś przyszyto do niej po zapisaniu ostatniej składki ${ }^{54}$. Kodeks ma paginację ołówkową z II połowy XX w., według której liczy 720 stron, co jest zgodne ze stanem faktycznym. Jest zbudowany z 41 składek pa-

${ }^{53}$ Edycja odczytanych not z oprawy rękopisu o sygnaturze 160, zob.: K. Nabiałek, Registrum hominum..., s. 176-177, 179, 181-182 (nr 140-151, 161-163, 171-182). Większość wpisów jest jednak nieczytelna z powodu zatarcia oraz ze względu na umieszczenie części tekstu pod grzbietem.

${ }^{54} \mathrm{Na}$ oddzielne użytkowanie pergaminu jeszcze przez dłuższy czas po $1474 \mathrm{r}$. wskazują noty z lat 1477-1499, wpisane na jego wewnętrznej stronie, w tym również na części grzbietowej (zob.: ibidem, s. $151,176-177,179,181-182)$. 
pierowych o różnej liczbie kart - od 4 do 14 (najczęściej 8 kart, tj. 4+4), ale w większości regularnych ( $\mathrm{tj}$. złożonych z podwójnych kart). Wyjątkiem jest składka 41 (ostatnia), złożona faktycznie z dwóch składek: do seksterniona (s. 689-704 i 713-720) między karty 8 i 9 (między s. 704 a 713) dołożono luźno binion (s. 705-712). Obecnie zatem ta złożona składka ma postać $6+6+4$. Ponadto nie jest ona przyszyta do oprawy.

Budowa i paginacja składek kodeksu jest następująca: składka 1: 7+7 (s. 1-28); 2: 6+6 (s. 29-52); 3: 4+4 (s. 53-68); 4: 4+4 (s. 69-84); 5: 2+2 (s. 85-92); 6: 2+2 (s. 93-100); 7: 4+4 (s. 101-116); 8: 4+4 (s. 117-132); 9: 4+4 (s. 133-148); 10: 4+4 (s. 149-164); 11: 4+4 (s. 165-180); 12: 5+5 (s. 181-200); 13: 4+4 (s. 201-216); 14: 4+4 (s. 217-232); 15: 4+4 (s. 233-248); 16: 4+4 (s. 249-264); 17: 4+4 (s. 265-292); 18: 4+4 (s. 293-308); 19: 4+4 (s. 309324); 20: $2+2$ (s. 325-332); 21: 2+2 (s. 333-340); 22: 6+6 (s. 341-364); 23: 4+4 (s. 365-380); 24: 2+2 (s. 381-388); 25: 6+6 (s. 389-412); 26: 6+6 (s. 413436); 27: 6+6 (s. 437-460); 28: 6+6 (s. 461-484); 29: 4+4 (s. 485-500 - luźna, nie jest przyszyta do oprawy); 30: 4+4 (s. 501-516); 31: 4+4 (s. 517-532); 32: 4+4 (s. 533-548); 33: 6+6 (s. 549-572); 34: 4+4 (s. 573-588 - luźna, nie jest przyszyta do oprawy); 35: 3+3 (s. 589-600); 36: 6+6 (s. 601-624); 37: 6+6 (s. 625-648); 38: 2+2 (s. 649-656); 39: 4+4 (s. 657-672); 40: 4+4 (s. 673-688); 41: 6+6+4 (s. 689-720).

We wszystkich składkach, z wyjątkiem 32, są wyraźne ściegi; w zdecydowanej większości składek pod szyciem zostały umieszczone też zszywki pergaminowe - brak ich tylko w 13 składkach: 29 i 30 oraz 32-41. Składka 24 (s. 381388) została wszyta niewłaściwie, gdyż powinno się ją połączyć ze składkami rękopisu o sygnaturze 167, co już wyjaśniono przy jego opisie.

Na papierze tworzącym składki rękopisu stwierdzono co najmniej 27 różnych znaków wodnych:

1. Skrzyżowane klucze z krzyżem na pręcie podwójnym, o wymiarach: 138 x $34 \mathrm{~mm}$ (s. 3-4, 9-10, 43-44, 47-48, 51-52).

2. Głowa wołu z różą siedmiolistną na pręcie pojedynczym między rogami, o wymiarach: 133 x $34 \mathrm{~mm}$ (s. 13-16).

3. Głowa wołu z wysokim krzyżem na pręcie podwójnym między rogami, o wymiarach: 133 x $34 \mathrm{~mm}$ (s. 63-64 i 67-68).

4. Głowa wołu $\mathrm{z}$ różą sześciolistną na pręcie podwójnym, $\mathrm{z}$ trzema promieniami w dół, o wymiarach: 151 x $38 \mathrm{~mm}$ (s. 79-82).

5. Głowa wołu w koronie $\mathrm{z}$ różą sześciolistną na pojedynczym pręcie, o wymiarach: 153 x $35 \mathrm{~mm}$ (s. 91-92).

6. Skrzyżowane klucze z krzyżem na pręcie podwójnym, o wymiarach: 158 x 38 mm (s. 97-98).

7. Głowa wołu w koronie $\mathrm{z}$ różą sześciolistną na pręcie podwójnym, $\mathrm{z}$ promieniami z boku pręta, o wymiarach: 105 x $45 \mathrm{~mm}$ (s. 111-112, 112116). 
8. Głowa wołu z krzyżem na pręcie podwójnym, wsparta na odwróconej koronie, o wymiarach: 142 x 38 mm (s. 125-126, 129-130, 143-144, 147-148).

9. Głowa wołu z różą pięciolistną na pręcie pojedynczym, z grotem wychodzącym w dół na pręcie pojedynczym z dwoma poprzecznymi prętami, o wymiarach: 158 x $31 \mathrm{~mm}$ (s. 157-158, 161-162, 211-212, 213-214, 225-226).

10. Głowa wołu z różą sześciolistną na pręcie podwójnym, o wymiarach: 112 x 35 mm (s. 173-174, 165-166 i 179-180, 181-182, 193-194, 195196).

11. Głowa wołu z koroną na podwójnym pręcie, a nad nią róża sześciolistna, o wymiarach: 159 x $35 \mathrm{~mm}$ (s. 217-218).

12. Głowa wołu z krzyżem na pręcie podwójnym oplecionym przez węża, o wymiarach: 143 x $39 \mathrm{~mm}$ (s. 239-240, 245-246, 253-254, 273-274 i 283-284).

13. Głowa wołu z krzyżem na pręcie podwójnym oplecionym przez węża, o wymiarach: 139 x 34 mm (s. 251-252, 267-268 i 289-290, 277-280).

14. Dzban?, o wymiarach: około 30 x 25 mm (s. 293-294, 297-298).

15. Głowa wołu z koroną na podwójnym pręcie, $\mathrm{z}$ różą siedmiolistną nad nią, o długości: około $153 \mathrm{~mm}$ (s. 309-310, 323-324, 313-314, 319-320).

16. Głowa wołu z krzyżem na pręcie podwójnym oplecionym przez węża, o wymiarach: 167 x 39 mm (s. 325-326 i 331-332).

17. Głowa wołu z krzyżem na pręcie podwójnym oplecionym przez węża, o wymiarach: 151 x 40 mm (s. 333-334, 339-340).

18. Głowa wołu z krzyżem potrójnym (egipskim) na pojedynczym pręcie, o wymiarach: 50 x $23 \mathrm{~mm}$ (s. 343-344, 351-352, 357-358, 383-384).

19. Głowa wołu z krzyżem na pręcie podwójnym oplecionym przez węża, o wymiarach: $141 \mathrm{x} 44 \mathrm{~mm}$ (s. 365).

20. Głowa wołu z krzyżem egipskim na pojedynczym pręcie, o wymiarach: 66 x 28 mm (s. 371-374, 395-396 i 405-406, 397-398 i 403-404, 399-402, 413-414 i 435-436, 417-418 i 431-432, 421-422 i 427-428, 439-440 i 457-458, 443-444 i 453-454, 447-450, 463-464 i 481-482, 467-468 i 477-478, 471-474).

21. Głowa wołu z krzyżem na pręcie podwójnym oplecionym przez węża, o wymiarach: 180 x $48 \mathrm{~mm}$ (s. 485-486 i 499-500, 495-496, 537-538 i 543-544, 547-548, 549-550 i 571-572, 553-554 i 567-568, 559-662, 593-594, 603-606, 609-610).

22. Głowa wołu z różą pięciolistną na pojedynczym pręcie z grotem wychodzącym w dół na pręcie pojedynczym, o wymiarach: około 166 x $50 \mathrm{~mm}$ (s. 501-502 i 515-516, 505-506 i 511-512, 659-660, 661-662). 
23. Głowa wołu z różą pięciolistną na pojedynczym pręcie z grotem wychodzącym w dół na pręcie pojedynczym, o długości: 142 x 45 mm (s. 529530 i 531-532).

24. Korona zamknięta z krzyżem na pręcie podwójnym, o wymiarach: 153 x 39 mm (s. 573-574, 579-580).

25. Półksiężyc z krzyżem egipskim na pręcie podwójnym, o długości: około 66 mm (s. 625-626 i 647-648, 631-632 i 641-642, 635-638).

26. Świnia lub dzik, o wymiarach: 52 x 35 mm (s. 649-650 i 655-656, 673674 i 687-688, 677-678 i 683-684).

27. Korona zamknięta $\mathrm{z}$ krzyżem na pręcie podwójnym, o wymiarach: 136 x 46 mm (s. 693 i 715, 699-700 i 701-702, 707-708 i 709-710).

W bazach filigranów udało się odnaleźć znaki podobne dla: nr 1 (Nördlingen - 1469 r. lub Kolonia - 1477 r.) $)^{55}$, nr 8 (Brescia - 1475 r.) ${ }^{56}$, nr 9 (Gotteszell 1477 r., Regensburg - 1476 r., Freiberg, Sachsen -1475 r.) ${ }^{57}$, nr 10 (Norymberga -1469 r. $)^{58}$.

Zarówno ze względu na zawartość, jak i na formę, rękopis można określić jako księgę ławniczą miasta Proszowic ${ }^{59}$. Zawiera on dokumentację działalności sądu ławniczego z lat 1474 (data pierwszego sądu: 6 maja) - 1511 (data ostatniego sądu: 24 stycznia) $)^{60}$.

Otwarta pozostaje kwestia zależności tego rękopisu wobec równolegle prowadzonej księgi ławniczej, zachowanej w postaci nieoprawionych składek z II połowy XV i początku XVI w., opisanej wcześniej (sygn. 167). Bez szczegółowej analizy wpisów nie sposób porównać jednak zawartości obu rękopisów Na obecnym etapie można jedynie stwierdzić, że obie jednostki były spisywane równolegle, gdyż w obu wprowadzane były wpisy z tych samych sesji sądu gajonego. Wstępne rozpoznanie nie pozwala jednak na wskazanie wyraźnych różnic między obu księgami pod względem treści, a więc i wartości prawnej wpisów. O tym, że takiego rozróżnienia nie stosowała również kancelaria miejska świadczy wspomniane błędne oprawienie w rękopisie 160 składki, która przynależy do ciągu składek rękopisu 167. Można za to uznać, że kontynuacją kodeksu 160 jest rękopis o sygnaturze 161.

\footnotetext{
${ }^{55}$ Baza internetowa: www.piccard-online.de [dostęp: 01.02.2018], nr 121266, 121298.

${ }^{56} \mathrm{Ibidem}, \mathrm{nr} 68708$. Znak prawdopodobnie identyczny - w rękopisie 160 na kartach z wpisami $\mathrm{z} 1478 \mathrm{r}$.

${ }^{57}$ Ibidem, nr 66114, 66118, 66124.

${ }^{58}$ Ibidem, nr 70016.

59 Rękopis ten niewątpliwie ma komplet czterech cech wskazanych przez Marcina Grulkowskiego, które winny spełniać księgi miejskie (idem, op.cit, s. 124-125; zob. przypisy 28 i 29).

${ }^{60} \mathrm{Na}$ ostatniej stronie (s. 720) przy jednym z wpisów została dodana inną ręką nota: Reformacio eiusdem inscripcionis vide infra sub advocato Stefano Spitarski feria sexta post Viti [18 VI] anno 1512. Jest to z pewnością odsyłacz do fragmentu akt ławniczych spoza opisywanego tomu. Sformułowanie zawarte w nocie (infra) może wskazywać, że w czasie sporządzenia uwagi ostatnia składka funkcjonowała poza kodeksem o sygnaturze 160, wśród innych nieoprawionych jeszcze akt ławniczych.
} 


\section{Fragment księgi lawniczej Proszowic z lat 1512-1513}

Jest to $\mathrm{w}$ zasadzie jedna składka przechowywana wraz $\mathrm{z}$ fragmentami ksiąg miejskich Lelowa z XVI w. w ANK w rękopisie z zespołu Variae civitates et villae (nr 29/121/0), oznaczonym sygnaturą 112 (dawna sygn. IT 230b) ${ }^{61}$. Jest to oryginalna, składka, z wyraźnym ściegiem w środku, licząca cztery karty $(2+2)$, o wymiarach 11,1 x 32,4 cm (format dutki). Składka ta w jednostce archiwalnej była wcześniej przechowywana wraz z innymi składkami akt ławniczych Proszowic (obecnie sygn. 167), o czym świadczy paginacja ołówkowa, ale przy porządkowaniu nie została wraz z nimi oddzielona od ksiąg lelowskich. Na dole kart znajduje się podwójna paginacja sporządzona przez archiwistów - wcześniejsza, przekreślona (s. 505-512) i aktualna (s. 631-638), która stanowi jeden wspólny ciąg z dalszymi składkami w obrębie jednostki archiwalnej, zawierającymi akta ławnicze Lelowa. Na kartach: drugiej (s. 633-634) i trzeciej (s. 635-636) - po części - znajduje się znak wodny - głowa wołu z krzyżem na podwójnym pręcie oplecionym przez węża. Składka zawiera wpisy dokonane na posiedzeniu sądu ławniczego Proszowic od 25 czerwca 1512 r. do 19 listopada 1513 r. Na uznanie tej składki za fragment odrębnego tomu akt ławniczych pozwala porównanie jej formatu oraz schematu pisarskiego z innymi zachowanymi księgami ławniczymi z przełomu XV i XVI w. (inny schemat pisarski niż w składkach rękopisu o sygn. 167, a znacznie mniejszy format niż kodeks o sygn. 161). Nie można jednak wykluczyć, że była ona przechowywana wraz z zespołem luźnych składek, które kończą się na roku 1509 (sygn. 167), a brak ciągłości wynika z późniejszego ich rozproszenia, a więc ze stanu zachowania zbioru.

\section{Księga lawnicza $z$ lat $1513-1533$}

Rękopis przechowywany $\mathrm{w}$ ANK, w zespole Variae civitates et villae (nr 29/121/0), oznaczony sygnaturą 161 (dawna sygn. Prosz. 2). Jest to kodeks papierowy o wymiarach kart 14,2 x 40,4 cm, z uszkodzoną oprawą, zachowaną szczątkowo - na grzbiecie znajdują się cztery podwójne zwięzy grzbietowe i szczątki dwóch kapitałek oraz z tyłu pergaminowy pasek (szerokości około połowy bloku kodeksu), złożony $\mathrm{z}$ dwóch różnych makulaturowych fragmentów (dokument z 1481 r. oraz karta kodeksowa z XV w.), który prawdopodobnie stanowił kartę ochronną ${ }^{62}$. Można przypuszczać, że pierwotna okładka była wykonana $z$ desek lub skóry usztywnionej tekturą. Rękopis jest paginowany: s. 3-310, co odpowiada rzeczywistej liczbie stron. Obecnie brakuje najpewniej trzech kart początkowych kodeksu; oprócz zaginionej paginowanej karty (s. 1-2) były

${ }^{61}$ Składka ta została zidentyfikowana podczas przygotowywania edycji najstarszego zachowanego fragmentu akt ławniczych Lelowa (K. Nabiałek, Fragment zaginionej księgi ławniczej..., s. 1295, przypis 9).

${ }^{62} \mathrm{Na}$ wykonanie oprawy tego kodeksu z makulatury pergaminowej zwróciła uwagę Agnieszka Bartoszewicz (eadem, Piśmienność mieszczańska ..., s. 71; eadem, Urban literacy..., s. 117 - zdjęcie fragmentu oprawy z kartą ochronną). 
zapewne jeszcze dwie inne, które prawdopodobnie tworzyły pierwszą składkę licząca 12 kart (seksternion), wraz z pierwszą kartą zachowaną obecnie w postaci szczątkowej (s. 3-4), z kolejnymi czterema kartami połączonymi ściegiem (s. 5-12), a także ze znajdującymi się za nimi czterema luźnymi kartami (s. 1320).

Druga składka to seksternion (s. 21-44) - choć karta pierwsza (s. 21-22) jest luźna, to odpowiada ona pojedynczej karcie z końca składki (s. 43-44), co potwierdza znak wodny (głowa wołu z krzyżem na pręcie podwójnym między rogami), znajdujący się częściowo na obu stronach. Kolejne trzy składki to regularne i zachowane $\mathrm{w}$ całości kwinterniony, paginowane odpowiednio: trzecia - s. 45-64, czwarta - s. 65-84, piąta - s. 85-104. Następne składki - od szóstej do jedenastej to seksterniony: szósta - s. 105-128, siódma - s. 129-152, ósma - s. 153-172 (z tym że karta 12 - s. 171-172 - jest luźna, ale odpowiada pojedynczej i przytwierdzonej do składki karcie pierwszej - s. 153-154), dziewiąta - s. 173-196, dziesiąta - s. 197-220, jedenasta - s. 221-244. Składka dwunasta to kwinternion (s. 245-264), a trzynasta to seksternion (s. 265-288). Znajdująca się na końcu kodeksu, przed okładką ostatnia - czternasta składka zapewne była seksternionem, ale obecnie brakuje ostatniej karty, więc jest to składka niepełna 6+5 (s. 289-310), w dodatku mocno uszkodzona, bo pierwsze dwie karty (s. 289-292) są luźne, podobnie jak 11 karta składki, obecnie ostatnia (s. 309-310), zachowana szczątkowo; pomiędzy nimi znajduje się osiem kart z wyraźnym ściegiem w środku.

W środku wszystkich składek znajdują się ściegi, ale bez wzmocnień w postaci zszywek. W całym kodeksie występują dwa znaki wodne: litera „P” z rozdwojoną laską na dole $(42 \times 16 \mathrm{~mm})$ oraz głowa wołu z krzyżem na pręcie podwójnym między rogami ( 108 x $56 \mathrm{~mm})$. Filigrany występują na wszystkich arkuszach papieru tworzących składki, są podzielone na obie strony (choć nieregularnie), co daje możliwość kontrolowania lub rekonstrukcji budowy składek.

Księga zawiera wpisy dokonane na sądach ławniczych gajonych od 7 października 1513 r. (data na s. 5) do10 października 1533 r. (data na s. 308).

\section{Księga lawnicza z lat 1550-1567}

Rękopis przechowywany w ANK, w zespole Variae civitates et villae (nr 29/121/0), oznaczony sygnaturą 162 (dawna sygn. Prosz. 3). Jest to kodeks papierowy o wymiarach kart 15 x 39,5 cm, z uszkodzoną oprawą. Stanowily ją najpewniej deski niepokryte skórą. Obecnie zachował się grzbiet z czterema podwójnymi zwięzami, wzmocnionymi dodatkowo czterema pergaminowymi paskami (zapisana makulatura z tekstem z XV w.) oraz dolna okładka o formacie wielkości bloku kodeksu. Przy desce znajdują się kawałki skóry przybite gwoździami na metalowych podkładkach, które stanowią pozostałość po paskach służących do zamykania kodeksu; na desce od wewnątrz niewielkie fragmenty papieru (druk z XVI w.), które zapewne są pozostałością dawnej wyklejki; bez- 
pośrednio na desce po wewnętrznej stronie umieszczona jest nota: Valentinus notarius cuius hoc in officio [...] egit 1554. Kodeks ma paginację ołówkową (s. 1-574), która odpowiada rzeczywistej liczbie stron.

Składki rękopisu są najpewniej zachowane w komplecie, a jedynie pierwsza karta rękopisu (s. 1-2) jest uszkodzona - oderwana część około 1/3 długości od góry. Kodeks składa się z 37 składek papierowych; prawie wszystkie to kwaterniony, z wyjątkiem składek 14 (s. 209-220) i 32 (s. 491-502), które są ternionami oraz ostatniej składki 37 - binion (s. 567-574), a także nieregularnej składki 18 (s. 269-282), w której brakuje szóstej karty (jest ślad po obcięciu), więc ma budowę 4+3. Pozostałe składki (4+4) są paginowane następująco: 1: s. 1-16; 2: s. 17-32; 3: s. 33-48; 4: s. 49-64; 5: s. 65-80; 6: s. 81-96; 7: s. 97-112;8: s. $113-128 ; 9$ : s. $129-144 ; 10$ : s. $145-160 ; 11$ : s. 161-176; 12: s. 177-192; 13: s. $193-208 ; 15$ : s. $221-236 ; 16$ : s. $237-252 ; 17$ : s. 253-268; 19: s. 283-298; 20 : s. $299-314 ; 21$ : s. $315-330 ; 22$ : s. 331-346; 23: s. 347-362; 24: s. 363-378; 25 : s. 379-394; 26: s. 395-410; 27: s. 411-426; 28: s. 427-442; 29: s. 443-458; 30 : s. $459-474 ; 31$ : s. $475-490 ; 33$ : s. 503-518; 34: s. 519-534; 35: s. 535-550; 36: s. 551-566.

Księga zawiera wpisy dokonane na sądach ławniczych gajonych od sesji przed 11 września 1550 r. (data na s. 3) do 10 stycznia 1567 r. (data na s. 565). Trzy ostatnie strony (s. 572-574) są puste. Na ostatniej zapisanej stronie (s. 571) pisarz (Łukasz z Ciechanowa, który rozpoczął wpisy w rękopisach o sygn. 163 i 164) w sposób ozdobny zakreślił atramentem wolne miejsce i dodał notę: Finis Actorum Scabinalium.

\section{Księga lawnicza z lat 1567-1572}

Rękopis przechowywany w ANK, w zespole Variae civitates et villae (nr 29/121/0), oznaczony sygnaturą 163 (dawna sygn. Prosz. 4). Jest to kodeks papierowy o wymiarach kart 15,5-15,7 x 39,6-40 cm, posiadający oryginalną renesansową oprawę, której okładki wielkości bloku kodeksu są wykonane ze skóry usztywnionej papierowymi kartami (w górnej okładce wypadły i są umieszczone luźno); na grzbiecie cztery podwójne zwięzy grzbietowe. Skórzana okładka tłoczona na zewnątrz ze zdobieniami, przedstawiającymi półpostaci cesarzy, umieszczonymi w arkadach z nadpisanymi majuskułą imionami („FERDI”, „LVDOVI”, „CAROLVS”) i datą „1540”63. Rękopis ma paginację ołówkową (s. 1-388), która odpowiada rzeczywistej liczbie stron.

Kodeks składa się z 25 regularnych i pełnych składek, które w zasadzie są kwaternionami, z wyjątkiem dwóch z nich: pierwszej - ternion (s. 1-12) i trzeciej - kwinternion (s. 29-48). Pozostałe składki są paginowane następująco: składka

${ }^{63}$ Prawdopodobnie tego samego radełka użyto do wykonania zdobień okładki księgi wikariatu generalnego krakowskiego z lat 1538-1540 (E. Knapek, Akta oficjalatu $i$ wikariatu generalnego krakowskiego do połowy XVI wieku, Kraków 2010, s. 262). Można więc przypuszczać, że rękopis oprawiono w Krakowie. 
2: s. 13-28; 4: s. 49-64; 5: s. 65-80; 6: s. 65-80; 7: s. 81-96; 8: s. 97-112; 9: s. $113-128 ; 10$ : s. $129-144 ; 11$ : s. $145-160 ; 12$ : s. $161-180 ; 13$ : s. $181-196 ; 14$ : s. $197-212 ; 15$ : s. $213-228 ; 16$ : s. $229-244 ; 17$ : s. $245-260 ; 18$ : s. $261-276 ; 19$ : s. 277-292; 20: s. 293-308; 21: s. 309-324; 22: s. 325-340; 23: s. 341-356; 24 : s. $357-372 ; 25$ : s. 373-388.

Księga zawiera wpisy dokonane na sądach ławniczych gajonych z kolejnych lat od 24 stycznia 1567 r. (data na s. 5) do 7 marca 1572 r. (data na s. 367). Niezapisane są strony na początku: 1, 3, 4 oraz cztery ostatnie: $385-388$. Na odwrocie pierwszej karty rękopisu (s. 2) znajduje się nota pisarza Łukasza zapewne z Ciechanowa o rozpoczęciu przez niego redagowania księgi od 24 stycznia 1567 r.: Hec Acta incepta sunt per me Lucam a Cziechanow artium ingenuarum Bacc [alarium] Gymnasiarcha necnon Notarius Civitatis Prossouien[sis] in Vigilia Conversionis s. Pauli sexta feria anno fere iam vertente officii mei Anni Domini $1567^{64}$. Ręką tego pisarza są prowadzone wpisy od początku, tj. od strony 5 na pewno do strony 126 (do 21 stycznia 1569 r.); od strony 126 dukt się zmienia, pismo staje się bardziej kaligraficzne i wygląda na dzieło innej ręki. Jednak taki sam kształt mają litery we wszystkich nagłówkach sądów od początku księgi. Być może zatem od strony 126 do strony 202 nadal prowadził wpisy Łukasz, lecz zmienił dukt pisma na bardziej ozdobny ${ }^{65}$. Na stronie 202 ręka już z pewnością się zmienia i przez kolejnego pisarza kodeks jest prowadzony do końca (do s. 384).

\section{Księga lawnicza $z$ lat $1567-1588$}

Rękopis przechowywany $\mathrm{w}$ ANK, w zespole Variae civitates et villae (nr 29/121/0), oznaczony sygnaturą 164 (dawna sygn. Prosz. 5). Jest to kodeks papierowy o wymiarach kart 15-15,5 x 40,5 cm, ze szczątkami dawnej oprawy (zachowany grzbiet bez pokrycia z czterema podwójnymi zwięzami, wzmocniony paskami pergaminowymi), umieszczony luźno w tekturowej okładce zapewne z XX w. ${ }^{66}$ Rękopis ma paginację ołówkową: s. 1-478, która odpowiada rzeczywistej liczbie stron. Pierwsza karta (s. 1-2) jest uszkodzona - oderwana częściowo na górze i na dole.

Kodeks składa się z 30 składek papierowych; prawie wszystkie to kwaterniony, z wyjątkiem składki ósmej (s. 113-124) i dwunastej (s. 181-192), które są ternionami oraz dwóch kwinternionów - dziewiątej (s. 125-144) i dziesiątej (s. 145-164). Ponadto ostatnia składka - 30 (s. 465-478), która pierwotnie najpewniej była regularnym kwaternionem, obecnie ma budowę 4+3 (a ściślej

${ }^{64}$ Informacja o objęciu przez niego funkcji pisarza niespełna rok wcześniej zgadza się z datą rozpoczęcia wpisów jego ręki w poprzedniej księdze ławniczej - od 8 III 1566 r. do końca rękopisu (ANK, 29/121/0 Variae..., sygn. 29/121/0/-/162, s. 525-571).

${ }^{65}$ Zdaje się to potwierdzać nota pisarza Łukasza w rękopisie (ibidem, sygn. 29/121/0/-/164); zob. przypis 67.

${ }^{66} \mathrm{~W}$ tekturowej okładce wraz z kodeksem jest umieszczona luźna karta z XVIII w. 
4+2+1), gdyż dla pierwszej karty (s. 465-467) brakuje odpowiednika, czyli karty ósmej, a z kolei ostatnia karta w kodeksie (s. 477-478), czyli siódma w składce, odpowiadająca karcie drugiej (s. 467-468), jest luźna (a przy tym jest uszkodzona, z dużym ubytkiem). Pozostałe składki są paginowane następująco: składka 1: s. 1-16; 2: s. 17-32; 3: s. 33-48; 4: s. 49-64; 5: s. 65-80; 6: s. 81-96; 7: s. 97-112; 11: s. 165-180; 13: s. 193-208; 14: s. 209-224; 15: s. 225-240; 16 : s. 241-256; 17: s. 257-272; 18: s. 273-288; 19: s. 289-304; 20: s. 305-320; 21 : s. 321-336; 22: s. 337-352; 23: s. 353-368; 24: s. 369-384; 25: s. 385-400; 26: s. 401-416; 27: s. 417-432; 28: s. 433-448; 29: s. 449-464.

Na papierze kodeksu znajduje się jeden typ znaku wodnego - tarcza herbowa $\mathrm{z}$ koroną (ten sam filigran jest w rękopisie o sygn. 163), we wszystkich składkach, podzielony na obie strony.

Księga zawiera wpisy dokonane na sądach ławniczych gajonych z kolejnych lat od 24 stycznia 1567 r. (data na s. 5) do 7 października 1588 r. (data na s. 476). Na początku kodeksu są niezapisane dwie strony: pierwsza i czwarta. $\mathrm{Na}$ odwrocie pierwszej karty rękopisu (s. 2) znajduje się nota pisarza (podobna jak w tomie o sygn. 163), informująca o okresie pełnienia przez niego funkcji w szkole i kancelarii: In nomine Domini amen. Lucas a Cziechanow arcium ingenuarumBacc[alarius]praefuitludoli[te]rarioProssouien[si] atquehincofficio notariatus quadriennio cum trimastri ${ }^{67}$. Na górze strony trzeciej wpisane noty sentencje, które są cytatami z trzech ksiąg Biblii (Mądrości 1, 1; Przysłów 17, 7 i Eklezjastesa 13,30). Właściwe wpisy zaczynają się od strony piątej i wszystkie kolejne strony do końca kodeksu są zapisane.

Data początkowa wpisów i nota pisarza potwierdzają, że księga ta została założona równocześnie z rękopisem o sygnaturze 163, jednak była ona kontynuowana znacznie dłużej. Choć oba tomy nie były prowadzone przez tą samą liczbę lat - drugi kodeks kończy się wpisami za 1572 r. - to można się domyślać, że musiała istnieć jego kontynuacja w postaci równoległego tomu (niezachowanego obecnie). Świadczy o tym nota w rękopisie 164 na stronie 255 z 1578 r. wyraźnie odwołująca się do innej księgi ławniczej z tego czasu (Vide prius iuditium $[s]$ banitum in alia parte post Conductus Paschae).

\section{Księga kryminalna $\mathrm{z}$ lat 1581-1686}

Rękopis przechowywany w ANK, w zespole Variae civitates et villae (nr 29/121/0), oznaczony sygnaturą 165 (dawna sygn. Prosz. 6). Jest to kodeks papierowy o wymiarach kart 9,8-10 x 31,2 cm (format dutki), z uszkodzoną

${ }^{67}$ Nota została wpisana przez Łukasza najpewniej na zakończenie pełnienia przez niego funkcji pisarza miejskiego Proszowic. Wpisy jego ręki zaczynają się od 8 III 1566 r. (ANK, 29/121/0 Variae..., sygn. 29/121/0/-/162, s. 525), a od 2 VI 1570 r. następuje wyraźna zmiana ręki w obu równolegle prowadzonych księgach (ibidem, sygn, 29/121/0/-/163, s. 202; sygn. 29/121/0/-/164, s. 71). Zgadza się to z podanym w nocie okresem pełnienia przezeń funkcji nauczyciela i pisarza - cztery lata i trzy miesiące. 
oprawą pergaminową - zachowana dolna okładka z pergaminu typu południowego, o wymiarze bloku kodeksu oraz grzbiet z trzema zwięzami. Górna część okładki zapewne dość dawno odpadła od rękopisu, gdyż pierwsza strona jest brudna, z mocno zatartym tekstem. Ostatnia karta (s. 175-176) jest uszkodzona - oderwana od góry. Rękopis ma paginację ołówkową (s. 1-176), która odpowiada rzeczywistej liczbie stron.

Kodeks składa się z 11 regularnych składek papierowych 4+4, które są paginowane następująco: składka 1: s. 1-16; 2: s. 17-32; 3: s. 33-48; 4: s. 49-64; 5: s. 65-80; 6: s. 81-96; 7: s. 97-112; 8: s. 113-128; 9: s. 129-144;10: s. 145-160; 11: s. $161-176$.

Zawartość rękopisu stanowią wpisy dotyczące spraw kryminalnych dokonane przed sądem ławniczym (wójta $\mathrm{z}$ ławnikami) na sesjach potrzebnych gajonych (iudicium necessarium, iudicum arduum expositum bannitum) oraz przed urzędem radzieckim (coram officio consulari) w okresie ponad 100 lat - od 17 marca $1581 \mathrm{r}$. (data na s. 2) (68 $^{6}$ do 10 maja 1686 r. (data na s. 167, ale wpis sprawy do s. 170). Strony niezapisane: 145-152, 171-173, 176. Choć daty poszczególnych wpisów pochodzą z różnych lat, przy czym zdarzają się kilkuletnie przerwy pomiędzy poszczególnymi datacjami (sprawy z lat: 1581-1612, 1615, 1619, 1620-1622, 1633, 1637, 1639, 1646-1647, 1653, 1665-1671, 1683, 1685-1686), to z pewnością kodeks stanowi zwartą księgę, która w tej postaci została założona już w 1581 r. Świadczą o tym znaki wodne, a ściślej jeden typ, występujący na papierze we wszystkich składkach oraz kontynuacja wpisów na stronach z kilku sąsiadujących składek (s. 16 i 17-19; s. 32 i 33; s. 48 i 49; s. 96 i 97, s. 112 i 113). W treści wpisów, obok skarg, zeznań oskarżonych oraz wyroków, zwracają uwagę liczne testamenty zeznane przez skazanych przed sądem ławniczym lub radą. Niektóre sprawy były rozpatrywane przez wójta i ławników na sesjach wyjazdowych w sąsiednich wsiach (Czulice, Siedliska, Klimontów). Warto podkreślić, że choć rękopis stanowi egzemplarz stosunkowo nielicznie zachowanego dla miast polskich typu źródła, jakim są księgi spraw karnych (kryminalnych), w dodatku z dużym przedziałem czasowym wpisów, to nie był on dotychczas znany i wykorzystywany naukowo ${ }^{69}$.

\section{Księga rachunkowa $z$ lat $\mathbf{1 7 6 8}-\mathbf{1 7 8 6}$}

Rękopis przechowywany w BPAU w Krakowie oznaczony sygnaturą $1207^{70}$. Jest to kodeks papierowy o wymiarach kart 8,8-9,2 x 31,1-31,3 cm (format dutki), z uszkodzoną oprawą, po której zostały dwa zwięzy grzbietowe i ślady po

\footnotetext{
${ }^{68}$ Data sądu wpisana na stronie pierwszej jest nieczytelna z powodu zatarcia tekstu.

${ }^{69}$ Nie wykorzystuje go znawca dziejów miejskiego prawa karnego Marian Mikołajczyk, idem, op.cit., zwłaszcza: s. 19-20, 375-377 (omówienie i wykaz cytowanych źródeł).

${ }^{70}$ BPAU w Krakowie, rękopis 1207. Ogólny opis rękopisu, zob.: J. Czubek, Katalog rękopisów Akademii Umiejętności w Krakowie, Kraków 1906, s. 203. Korzystał z tego kodeksu Franciszek Leśniak, określając go jako księgę rachunkową,jednak nie sporządził jego opisu, idem, op.cit., zob.: s. $118-119$.
} 
dwóch dalszych. Ma foliację ołówkową (k. 1-112), która odpowiada rzeczywistej liczbie kart.

Kodeks składa się zasadniczo z siedmiu składek papierowych (z wyraźnymi ściegami we wszystkich) oraz kilku luźnych kart między nimi. Budowa przedstawia się następująco: składka pierwsza - nieregularna: $5+6$ (k. 1-11) z wyraźnym ściegiem - brak drugiej karty w składce; dwie karty luźne (k. 12 i 13 - na obu kontynuacja treści z k. 11v oraz ten sam schemat pisarski); składka druga: $8+8$ (k. 14-29); składka trzecia: 8+8 (k. 30-45); luźne bifolium (k. 46-47 - na obu kartach taki sam schemat pisarski, jak w składce trzeciej); składka czwarta: $8+8$ (k. 48-63); pojedyncza karta luźna (k. 64 - kontynuacja treści z poprzedniej karty, tekst pisany tą samą ręką jak na k. 63v i 65); składka piąta: 7+7 (k. 65-78); pojedyncza karta luźna (k. 79 - identyczny schemat pisarski jak na następnej karcie); składka szósta: 8+8 (k. 80-95); składka siódma: 8+8 (k. 96-111); ostatnią kartą rękopisu jest pojedyncza karta luźna (k. 112). Karty niezapisane: 40v i 58v.

Kodeks zawiera wpisy wpływów i wydatków miejskich prowadzonych przez szafarzy (lonerów) Proszowic ${ }^{71} \mathrm{z}$ kolejnych lat od 1768 do 1786 r.

\section{Fragmenty ksiąg miejskich z XVII i XVIII w.}

Z okresu XVII-XVIII w., z wyjątkiem części zawartości opisanej już księgi kryminalnej oraz opisanej wyżej księgi rachunkowej, nie zachowała się w całości, tj. w postaci osobnego kodeksu, żadna księga rady ani ławy. W trzech jednostkach rękopiśmiennych o sygnaturach 440, 588 i 702, przechowywanych w BPAU w Krakowie ${ }^{72}$, znajdują się jednak fragmenty co najmniej kilku zaginionych dziś ksiąg ławniczych i radzieckich w postaci luźnych, pojedynczych kart, bifoliów, składek, a także poszytów. Jednostki rękopiśmienne, w których są fragmenty ksiąg miejskich Proszowic, to w zasadzie zbiory luźnych kart. Pierwszy z nich o sygnaturze 440 zawiera fragmenty rękopisów dotyczących różnych miast, w tym na kartach 115-166v - Proszowic, które zostały wspólnie oprawione, zapewne w XIX w. Dwie inne jednostki - o sygnaturach 588 i 702 - zawierają w zasadzie niemal wyłącznie fragmenty ksiąg Proszowic, będące dość przypadkowymi kolekcjami kart. Rękopis o sygnaturze 702, to zbiór luźnych kart bez oprawy ${ }^{73}$. Z kolei rękopis o sygnaturze 588 ma postać księgi, ale posiadają-

${ }^{71}$ O lonerach i prowadzeniu przez nich finansów miejskich, zob.: F. Leśniak, op.cit., s. 118-120.

72 Ogólny opis rękopisów, zob.: J. Czubek, op.cit., s. 75, 94, 116. Rękopis 440 pochodzi z daru Jana Smoniewskiego, zaś rękopisy 588 i 702 przekazał BPAU Cyprian Walewski. Zob.: B. Paloc-Schnaydrowa, Cyprian Walewski. Bibliofil i kolekcjoner (1820-1873), „Rocznik Biblioteki Polskiej Akademii Nauk w Krakowie” 1958, r. 4, s. 367-389; K. Dziwik, Jan Wincenty Smoniewski, historyk - zbieracz - bibliofil (1793-1867), ibidem, 1963, r. 9, s. 97-109; K. Grodziska, op.cit., s. 400; E. Knapek, Rękopisy średniowieczne w zbiorach Biblioteki Naukowej PAU i PAN w Krakowie, „Rocznik Biblioteki Nakowej PAU i PAN w Krakowie" 2012, r. 57, s. 43.

${ }^{73} \mathrm{~W}$ rkps 702 na k. 72-77, prócz fragmentów ksiąg miejskich Proszowic, znajdują się trzy bifolia, które stanowią bruliony ksiąg grodzkich krakowskich z końca XVI w. (na k. 72 i 76 data: 1596 r.). 
cej wtórną oprawę, zapewne z XIX w. lub z początku XX w., z nowymi kartami ochronnymi po obu stronach (przód i tył okładki) ${ }^{74}$. W obecnej postaci rękopis składa się z 225 kart o różnych wymiarach, najczęściej 16 x 20,4 cm (i mniej, zwłaszcza z powodu ubytków). Trudno odtworzyć jego budowę z powodu głębokiego wszycia kart w nowej oprawie. Tylko część kart można wyodrębnić ze względu na odmienne wymiary, przy czym odtworzenie poszczególnych składek jest niemożliwe bez rozcięcia oprawy.

Ze względu na brak możliwości ustalenia na podstawie szczątkowo zachowanego materiału, ile było tomów poszczególnych serii ksiąg, a także jaki okres one obejmowały, fragmenty z trzech rękopisów BPAU zostaną omówione zbiorczo dla całego okresu XVII-XVIII w., z rozdzieleniem na cztery części: akta ławnicze (wójtowsko-ławnicze), radzieckie, radziecko-ławnicze i rachunkowe.

\section{Fragmenty ksiąg lawniczych z XVII w. i z początku XVIII w.}

- Fragment księgi ławniczej z początku XVII w. (BPAU, rkps 702, k. 61-62). Bifolium o wymiarach kart około 20,3 x 31,6 cm. Wpisy dokonane na sądach gajonych ławniczych od 13 do 27 lutego $1604 \mathrm{r}$.

- Fragmenty księgi ławniczej z I połowy XVII w. (BPAU, rkps 702, k. 24 25). Bifolium o wymiarach kart 19,6 x 31,6 cm. Wpisy dokonane na sądach ławniczych gajonych od 8 czerwca do 18 lipca $1618 \mathrm{r}$.

- Fragment księgi wójtowsko-ławniczej z lat 30. i 40. XVII w. (BPAU, rkps 702 , k. 27-28). Bifolium o wymiarach kart 20,3 x $31,3 \mathrm{~cm}$, z śladami po szyciu. Obejmuje wpisy dokonane przed urzędem wójtowskim i sądem ławniczym 7 i 14 marca 1639 r. Na marginesie k. 28v znajduje się nota, dotycząca unieważnienia transakcji (Casstaum haec obligatio infra vide de Actu feria 2 da post Dominicam tertiam Paschae AD 1645), poświadczająca funkcjonowanie tych kart jako składki księgi, która była kontynuowana co najmniej do 8 maja $1645 \mathrm{r}$.

- Dwa fragmenty ksiąg ławniczych z lat 30. i 50. XVII w. (BPAU, rkps 588, k. 1-3). Jest to bifolium o wymiarach kart 16,4 x $20,5 \mathrm{~cm}$ (k. 2-3) z doklejoną kartą z przodu (k. 1), wszyte na początku rękopisu. Bifolium stanowi fragment składki z zachowanym śladem po ściegu. Trudno stwierdzić, kiedy została doklejona do niego karta, ale można przyjąć, że stało się to dopiero przy sporządzaniu obecnej oprawy. O sztucznym połączeniu tych kart świadczy zawartość. Na karcie pierwszej znajduje się wpisany majuskułą nagłówek z karty początkowej księgi wójtowsko-ławniczej (urzędu wójtowskiego) z datą rozpoczęcia jej prowadzenia od 1 listopada 1633 r.: Protocollon actorum officii advocatialis et scabinalis Prosoviensis. Natomiast karty druga i trzecia zawierają wpisy dokonane przed sądem ławniczym 21 maja i 1 grudnia $1655 \mathrm{r}$.

U góry pierwszych kart każdego z bifoliów znajdują się techniczne noty kancelaryjne: 39 Sexternus Rellationum (k. 76); 40 Sexternus Rellationum (k. 72); 41 Sexternus Rellationum / quartus (k. 74).

74 Jan Czubek w 1906 r. określił okładkę jako ,świeża” (idem, op.cit., s. 94), co oznacza, że oprawienie rękopisu wykonano na zlecenie Akademii Umiejętności. 
- Fragment księgi wójtowsko-ławniczej z II połowy XVII w. (BPAU, rkps 702, k. 29-30). Bifolium o wymiarach kart 20,2 x $31,8 \mathrm{~cm}$ ze śladami po przeszyciu w środku. Jest to fragment składki księgi, ale nie ze środka, a najpewniej z zewnątrz. Wyraźnie brakuje kilku kart między nimi, o czym przekonują daty oraz brak kontynuacji treści wpisów na k. 29 verso i k. 30 recto. Karty zawierają wpisy dokonane przed urzędem wójtowskim (na k. 29 określonym w nagłówku nawet jako podwójtowski: coram offcio viceadvocati et scabinorum) i na sądzie ławniczym od 23 listopada do 12 grudnia 1657 r. (k. 29-29v) oraz 25 kwietnia 1659 (k. 30v).

- Fragment księgi ławniczej z II połowy XVII w. (BPAU, rkps 588, k. 97$104 v)$. Karty zawierają wpisy dokonane przed sądem ławniczym 3 i 18 października 1667 r. (k. 97v), 18 i 21 września 1668 r. (k. 98) oraz od 8 stycznia do 19 kwietnia 1669 r. (k. 99-104v).

- Fragment księgi ławniczej z II połowy XVII w. (BPAU, rkps 588, k. 107$164 v)$. Karty zawierają wpisy dokonane przed sądem ławniczym od 30 kwietnia do 31 grudnia 1669 r. (k. 107-155v), od 10 stycznia do 11 marca 1670 r. (k. 156-164v).

- Fragment księgi ławniczej z lat 1670-1671 (BPAU, rkps 588, k. 22-81v). Wpisy dokonane przed sądem ławniczym od 2 maja do 30 grudnia $1670 \mathrm{r}$. (k. 22-48) i od 2 stycznia do 14 października 1671 r. (k. 48v-81v).

- Fragment księgi ławniczej z II połowy XVII w. (BPAU, rkps 702, k. 101104). Dwa złożone bifolia o wymiarach kart 20,5 x $32 \mathrm{~cm}$, które stanowią prawdopodobnie fragment oryginalnej składki ze śladami po przeszyciu. Wpisy dokonane przed sądem ławniczym i urzędem wójtowskim (coram officio) od 12 do 27 kwietnia $1678 \mathrm{r}$.

- Fragment księgi ławniczej Proszowic z II połowy XVII w. (BPAU, rkps 440 , k. 122-166v). Są to luźne karty - pojedyncze i bifolia - o wymiarach 18,419,6 cm x 29,9-32,4 cm, przy czym niektóre karty są uszkodzone z dużymi ubytkami, oprawione wtórnie $\mathrm{w}$ jednym tomie wraz $\mathrm{z}$ fragmentami innych rękopisów. W obecnej postaci trudno stwierdzić, jaki był wzajemny układ kart. Karty raczej pojedyncze to: $\mathrm{k} .122,123,126,131,134,135,146,147,156,159,160$, $161,162,163,164,165,166$. Karty połączone ze sobą (bifolia) to: 124-125, 127-128, 129-130, 132-133, 136-137, 138-139, 140-141, 142-143, 144-145, 148-149, 150-151, 152-153, 154-155, 157-158. Zawartość stanowią wpisy dokonane na sądach ławniczych gajonych: od 9 do13 grudnia 1678 (k. 122-122v - ułożona odwrotnie), od 9 do 20 stycznia 1679 r. (k. 124-143v), od 12 stycznia do 20 sierpnia 1680 r. (k. 144-164v) i od 11 listopada do 10 grudnia 1686 r. (k. 165-166v, 123-123v - karta zawiera najpóźniejszą datę sądu). W wypadku fragmentów z lat 1679, 1680 i 1686 możemy mówić o ciągłości wpisów na co wskazują niewielkie odstępy pomiędzy datami poszczególnych sądów.

- Fragment księgi ławniczej z II połowy XVII w. (BPAU, rkps 702, k. 31). Pojedyncza karta o wymiarach około 19,5 x 30,8 cm (ułożona odwrotnie). Wpi- 
sy dokonane przed sądem ławniczym 20 czerwca 1678 r. (k. 31v) i 20 września 1679 r. (k. 31).

- Fragment księgi ławniczej z II połowy XVII w. (BPAU, rkps 702, k. 93-94). Bifolium o wymiarach kart około 20 x $32 \mathrm{~cm}$; karty mocno zniszczone z boku i od dołu. Wpisy dokonane przed sądem ławniczym od terminu po 11 marca (feria [...] post dominicam Invocavit) do terminu między 25 a 27 czerwca $1685 \mathrm{r}$. (feria [...] post dominicam infra octavam Sanctissmi Corporis).

- Fragment księgi ławniczej z II połowy XVII w. (BPAU, rkps 702, k. 16). Luźna karta o wymiarach 17,4 x 29,3 cm, zapisana jednostronnie, zawierająca wpisy dokonane przed sądem ławniczym 29 kwietnia $1691 \mathrm{r}$.

- Fragment księgi ławniczej z II połowy XVII w. (BPAU, rkps 702, k. 117118). Bifolium o wymiarach kart 20,5 x 33,5-34 cm. Wpisy dokonane przed sądem ławniczym od 18 czerwca do 7 lipca $1693 \mathrm{r}$.

- Fragment księgi ławniczej z II połowy XVII w. (BPAU, rkps 702, k. 19-20, 21,22 ). Bifolium o wymiarach 19,7 x 29,6 cm (karty odwrotnie ułożone - poprawnie k. 20-19), które zapewne stanowiło zewnętrzną część grubej składki oraz dwie luźne karty o wymiarach 22,2 x $33,5 \mathrm{~cm}$ (k. 21) i 20,2 x 32,2 cm (k. 22). Tekst na k. 19, 21 i 22 został sporządzony tą samą ręką. Karty zawierają wpisy dokonane na sądzie ławniczym 2 czerwca 1680 r. (k. 20), 15 kwietnia 1693 r. (k. 19), 10 i 11 października 1694 r. (k. 22) i 21 października 1694 r. (k. 21: feria quinta post festum translationis sancti Adalberti).

- Fragment księgi ławniczej z II połowy XVII w. (BPAU, rkps 702, k. 34 35). Bifolium o wymiarach kart około $20 \times 32 \mathrm{~cm}$. Wpisy dokonane na sądzie lawniczym od 3 maja (k. 34: feria secunda in festo sancte Crucis) do 11 maja 1694 r. (k. 35v).

- Fragment księgi ławniczej z II połowy XVII w. (BPAU, rkps 702, k. 9192). Bifolium o wymiarach kart około 19,6 x $32 \mathrm{~cm}$. Wpisy dokonane przed sądem ławniczym od 11 sierpnia do 7 września $1694 \mathrm{r}$.

- Fragment księgi ławniczej z II połowy XVII w. (BPAU, rkps 702, k. 3660). Poszyt złożony z pojedynczych kart i bifoliów o wymiarach kart 19,5$20,1 \times 31,6-32,3 \mathrm{~cm}$. Wpisy dokonane przed sądem ławniczym od 29 kwietnia do 19 grudnia 1698 r. (k. 36-48) i od 5 stycznia do 7 września 1699 r. (k. 48-60v).

- Fragment księgi ławniczej z II połowy XVII w. (BPAU, rkps 702, k. 14 15). Bifolium o wymiarach kart 20,3 x 32,4 cm. Wpisy dokonane przed sądem ławniczym od 24 listopada do 15 grudnia $1699 \mathrm{r}$.

- Fragment księgi ławniczej z I połowy XVIII w. (BPAU, rkps 702, k. 1112). Bifolium o wymiarach kart 18,3 x $30 \mathrm{~cm}$ (ułożone odwrotnie - poprawnie k. 12-11). Wpisy dokonane przed sądem ławniczym od 19 marca do 15 kwietnia z $1706 \mathrm{r}$.

- Fragmenty księgi ławniczej z I połowy XVIII w. (BPAU, rkps 702, k. 32, 33). Dwie luźne karty o wymiarach 19 x $30,8 \mathrm{~cm}$. Karty są pisane tą sama ręką i mają atramentową paginację - zapewne historyczną (z XVIII w.?) na k. 32: 
197, na k. 33: 195. Wpisy dokonane przed sądem ławniczym w 1739 r. (bez daty dziennej).

\section{Fragmenty ksiąg radzieckich z XVII w. i początku XVIII w.}

- Fragment księgi radzieckiej z I połowy XVII w. (BPAU, rkps 702, k. 1-10). Składka papierowa - regularny kwinternion o wymiarach kart 19,8-20,1 x 32$32,8 \mathrm{~cm}$. Zapewne jest to początkowa składka księgi na co wskazuje nagłówek na k. 1: Protocollon actorum causarum Prosowicensium. Składka zawiera wpisy spraw dokonanych przed radą (coram officio proconsuli et consulis) od 23 marca do 19 lipca $1628 \mathrm{r}$.

- Fragment księgi radzieckiej z I połowy XVII w. (BPAU, rkps 588, k. 4-9). Regularna składka papierowa - ternion o wymiarach kart 15,5 x 19,8 cm, z wyraźnym ściegiem. Niedatowane wpisy dokonane przed radą (coram officio consulari). Na podstawie pisma można przyjąć, że tekst spisano prawdopodobnie w I połowie XVII w.

- Fragment księgi radzieckiej z II połowy XVII w. (BPAU, rkps 588, k. 1021). W obecnej postaci jest to nieregularna składka $4+4+2+2$, a więc kwaternion z dodanymi czterema kartami, o wymiarach kart 15,4-16 x 19-20,4 cm. Właściwa część składki obejmuje k. 10-15, 20-21 z wyraźnym ściegiem między k. 13 i 14. Dodane karty to dwa bifolia - pierwsze (k. 16-17) zostało doklejone do karty szóstej (k. 15), a drugie (k. 18-19) o wyraźnie mniejszych wymiarach kart $(14,9$ x 18,4 cm) przyklejono do karty siódmej (k. 20) pierwotnej składki. Składka ma foliację atramentową, zapewne historyczną, tj. z XVII w. (oznaczenia od 110 do 120 ), ale z pominięciem obecnej k. 19. Na kartach znajdują się wpisy dokonane przed radą (coram officio consulari) od 7 stycznia 1657 r. do 18 stycznia 1658 r. Daty układają się poprawnie w porządku chronologicznym, więc można mówić o ciągłości wpisów.

- Fragment księgi radzieckiej z II połowy XVII w. (BPAU, rkps 588, k. 105106v). Wpisy dokonane przed radą od 13 do 17 kwietnia $1669 \mathrm{r}$.

- Większy fragment księgi radzieckiej z II połowy XVII w. (BPAU, rkps 588, k. 165-225v). Wpisy dokonane przed radą od 30 lipca do 7 września $1674 \mathrm{r}$. (k. 165-174v), od 21 września do 30 grudnia 1678 r. (k. 175-188v) i od 2 stycznia do 2 lipca 1679 r. (188v-225v).

- Fragmenty księgi radzieckiej z II połowy XVII w. (BPAU, rkps 588, k. 8296v). Wpisy dokonane przed radą od 6 czerwca do 15 sierpnia 1670 r. (k. 82-88), 5 marca 1670 r. (k. 91v); 25 czerwca 1670 r. (k. 92-92v), od 9 do 22 września 1678 r. (k. 94-96v) oraz niedatowane wpisy (k. 93-93v).

- Fragment księgi radzieckiej z II połowy XVII w. (BPAU, rkps 702, k. 17). Luźna karta o wymiarach 19,1 x 31,5 cm, zapisana dwustronnie. Wpisy dokonane przed radą 20 grudnia $1684 \mathrm{r}$.

- Fragment księgi radzieckiej z II połowy XVII w. (BPAU, rkps 702, k. 23). Jest to pojedyncza karta o wymiarach 18,5 x $31,2 \mathrm{~cm}$, ale na odwrotnej stronie 
podzielona na dwie strony o wymiarach ok. 15,2-15,7 x 19,5 cm z wyraźnym ściegiem między nimi. Wpisy dokonane przed radą 9 maja $1685 \mathrm{r}$.

- Fragment księgi radzieckiej z II połowy XVII w. (BPAU, rkps 702, k. 25). Pojedyncza karta o wymiarach 18,8 x 19,8 $\mathrm{cm}$. Wpisy dokonane przed radą 30 stycznia $1686 \mathrm{r}$.

- Fragment księgi radzieckiej z II połowy XVII w. (BPAU, rkps 702, k. 7879). Bifolium o wymiarach kart około $18,5 \times 31,5 \mathrm{~cm}$. Zawiera wpisy dokonane przed radą od 5 do 16 października $1693 \mathrm{r}$.

- Fragment księgi radzieckiej z II połowy XVII w. (BPAU, rkps 702, k. 105116). Poszyt złożony z pojedynczych kart i bifoliów zszytych po jednej stronie (od grzbietu), o wymiarach kart 20,2 x 31,8-32,2 cm. Wpisy dokonane przed radą od 25 maja do 13 listopada 1693 r. Jest zachowana ciągłość dat w obrębie poszytu.

- Fragment księgi radzieckiej z końca XVII w. (BPAU, rkps 702, k. 70-71). Bifolium o wymiarach kart około 20,3 x 32,6 cm. Wpisy dokonane przez radą od 27 grudnia $1697 \mathrm{r}$. do 31 stycznia $1698 \mathrm{r}$.

- Fragmenty księgi radzieckiej z końca XVII w. (BPAU, rkps 702, k. 95-96, 97-100). Sześć kart prawdopodobnie pochodzących z jednej księgi: bifolium o wymiarach kart około 19,5 x 31,5 cm. (k. 95-96) oraz cztery karty w formie pozornej składki, a w rzeczywistości dwa bifolia wyjęte z różnych części księgi, o wymiarach kart około 20 x $31 \mathrm{~cm}$ (k. 97 i 100 oraz 98-99). Tekst na wszystkich kartach został sporządzony tą samą ręką. Wpisy dokonane przed radą 28 maja 1698 r. (k. 95-96), od 16 marca do 9 kwietnia 1699 r. (k. 97-100v) oraz od 13 października do 4 listopada 1699 r. (k. 98-99v).

- Fragment księgi radzieckiej Proszowic z I połowy XVIII w. (BPAU, rkps 702 , k. 80-84). Pięć luźnych kart o zbliżonych wymiarach: 19,6-20,3 x 32,4 cm, zapisanych tą samą ręką, które stanowią prawdopodobnie fragment jednego rękopisu. Wszystkie zawierają wpisy dokonane przed radą: 13 kwietnia $1726 \mathrm{r}$. (k. 80), 6 i 24 czerwca (k. 83, choć bez daty rocznej), 4 lipca 1726 r. (k. 82), 8 i 20 lipca 1726 r. (k. 84) oraz bez daty dziennej z 1726 r. (k. 81).

\section{Fragmenty akt urzędu i sądu lączonego (magistratu), czyli księgi radziecko-ławniczej z I połowy XVIII w.}

- Fragmenty księgi radziecko-ławniczej z I połowy XVIII w. (BPAU, rkps 702, k. 32, 33, 63, 64-69). Pierwszy fragment to regularna składka - ternion z wyraźnym ściegiem w środku (k. 64-69), o wymiarach kart 18,7 x 30,4 cm. $\mathrm{Na}$ wszystkich kartach u góry znajduje się atramentowa paginacja (historyczna, prawdopodobnie z XVIII w.) - od strony 198 do 209, która odpowiada układowi stron w składce. Karty zawierają wpisy spraw dokonanych przed urzędem radzieckim i sądem ławniczym (coram officio consulari et iudicio advocatiali scabinalique Prosouicensi) w 1739 r.: 6 listopada (k. 64), 27 listopada, 11 grudnia i 18 grudnia $(\mathrm{k} .68 \mathrm{v}-69 \mathrm{v})$. 
- Z tego samego rękopisu pochodzi zapewne pojedyncza karta (k. 63) o wymiarach około 19 x $30,9 \mathrm{~cm}$. (odwrotnie ułożona), na której tekst został sporządzony tą samą ręką jak w składce. Karta ma wpisany u góry atramentem numer 181 (zapewne foliacja historyczna). Zawiera wpisy dokonane przed połączonym urzędem radziecko-ławniczym wraz z trzecim ordynkiem (coram utroque magistratu officio Prossouicensi atque tota communitate) z 29 listopada $1739 \mathrm{r}$. (k. 63v) i 2 stycznia 1740 r. (k. 63).

- Również z tą samą księgą można łączyć dwie luźne karty (k. 32 i 33) o wymiarach 19 x 30,8 cm, które są pisane tą samą ręką co karty 63 i 64-69. Karty mają atramentową foliację - zapewne historyczną - na k. 32: 197, na k. 33: 195. Zawierają wpisy dokonane przed połączonym sądem radziecko-ławniczym (coram utroque magistratu) z 1739 r. (bez daty dziennej).

\section{Fragmenty ksiąg rachunkowych z XVII i XVIII w.}

- Fragment rachunków miejskich z początku XVII w. (BPAU, rkps 702, k. 18). Pojedyncza karta o wymiarach 19,1 x 29,7 cm (odwrotnie ułożona). Jest to fragment rachunków miejskich z przełomu 1602 r. (przed 13 grudnia, 13 grudnia, 16 i 17 grudnia) i 1603 r. (4 stycznia), a ściślej wydatków miejskich prowadzonych przez szafarza (lonera) Stanisława Baranka ${ }^{75}$. Na k. 18v nagłówek: „Summa Dochodow Rocznych miasta Proszowic pro Anno 1602”.

- Fragment rachunków miejskich z początku XVIII w. (BPAU, rkps 702, k. 119-120). Bifolium o wymiarach kart około $32,5 \times 20 \mathrm{~cm}$. Jest to fragment sumariusza wydatków miejskich z lat 1703-1708.

\section{Podsumowanie}

Niniejszy artykuł należy potraktować jedynie jako wstępne studium dotyczące ksiąg miejskich Proszowic, koncentrujące się przede wszystkim na próbie zinwentaryzowania i opisu kodykologicznego zachowanych i zidentyfikowanych rękopisów. Właściwe opracowanie tego zespołu źródeł wymaga szczegółowego zapoznania się z ich treścią oraz dokonania rekonstrukcji zarówno ustroju, jak i kancelarii miasta. Jest to zadanie badawcze na przyszłość.

$\mathrm{Na}$ obecnym etapie kwerend można stwierdzić, że zachowało się co najmniej 10 ksiąg miejskich Proszowic (wyłączono księgi cechowe ${ }^{76}$ ). Najstarsza,

${ }^{75}$ W XVII i XVIII w. za finanse miasta odpowiadali i prowadzili rachunki dwaj szafarze zwani lonerami. Pierwszym urzędnikiem znanym z nazwiska był Stanisław Baranek w 1603 r. (F. Leśniak, op.cit., s. 143-144, 146).

${ }^{76}$ Dokumentacji korporacji miejskich nie można uznać za księgi miejskie w sensie ścisłym, gdyż nie były wytworem kancelarii miejskich i nie reprezentowały całej wspólnoty miejskiej, lecz jej część (J. Tandecki, op.cit., s. 435-441; M. Grulkowski, op.cit., s. 127). Wypada jednak wspomnieć o najstarszej zachowanej księdze cechowej Proszowic i zarazem jednej z najstarszych z terenu Polski. W Bibliotece Jagiellońskiej w Krakowie znajduje się rękopis księgi cechu kowali i innych rzemiosł tego miasta (rkps 1111), założonej w 1483 r. Manuskrypt zawiera wpisy z XV, XVI i XVII w., za- 
z lat 1418-1456 - zawiera zasadniczo wpisy rady, a ponadto też rajców wraz $\mathrm{z}$ wójtem i ławnikami. Jeden $\mathrm{z}$ woluminów to księga rachunkowa $\mathrm{z}$ II połowy XVIII w; inny z kolei to księga kryminalna, zwierająca wpisy sądu ławniczego oraz rady. Siedem tomów to księgi ławnicze. Wszystkie księgi, z wyjątkiem jednej - rachunkowej, są przechowywane w Archiwum Narodowym w Krakowie. Ponadto dość liczne rozproszone fragmenty ksiąg tego miasta - ławniczych, radzieckich, radziecko-ławniczych - zachowały się w kilku rękopisach Biblioteki Naukowej PAU i PAN w Krakowie. Największe możliwości badawcze otwierają się więc wobec dokumentacji sądu ławniczego oraz urzędu wójtowskiego. W ramach ksiąg wójtowsko-ławniczych można zasadniczo wyróżnić dwie serie, które były prowadzone od XV w. Pierwsza ma postać składek bez oprawy (rkps 167), natomiast druga to kodeksy, czyli rękopisy oprawione (rkps 160). Na obecnym etapie badań nie jest możliwe wskazanie wyraźnych różnic treściowych między nimi w XV w. Można się spodziewać, że szczegółowa analiza formularza ksiąg i treści poszczególnych wpisów wskaże ich właściwą klasyfikację i powód ich założenia. Porównanie fragmentów najstarszej księgi miejskiej, zawierającej głównie wpisy rady, z księgą ławniczą z tego samego okresu (1. 1449-1452, 1454) pozwala stwierdzić, że obie serie redagował jeden pisarz miejski. Dowodzi tego w szczególności równoległa zmiana ręki w aktach obu instytucji, uchwytna nawet w tak krótkich przedziałach czasowych ${ }^{77}$.

Pewne obserwacje udało się poczynić dla ksiąg ławniczych z II połowy XVI w. Wstępne porównanie treści dwóch tomów z tego samego czasu (rękopisy o sygn. 163 i 164) prowadzi do kilku wniosków. Były one prowadzone równolegle i zawierają dokumentację bieżącą sądu ławniczego. Potwierdzają to notowane w obu jednostkach te same daty sądów gajonych od 24 stycznia 1567 r. do 7 marca 1572 r. (sygn. 163 od s. 5 do 367-384 - tj. do końca, do ostatniej zapisanej strony; sygn. 164 od s. 5 do 132-135). Wielokrotnie w jednej księdze wprowadzony jest wyłącznie nagłówek sądu bez wpisów, podczas gdy

sadniczo z 1. 1483-1645 oraz dwa późniejsze z 1800 r. (s. 44) i 1814 r. (s. 40), ale nie ma tu ciągłości i rękopis jest mocno wymieszany chronologicznie (W. Wisłocki, Katalog rękopisów Biblioteki Uniwersytetu Jagiellońskiego, cz. 1, Kraków 1877, s. 286; F. Kiryk, Dzieje Proszowic..., s. 37; idem, Miasto średniowieczne..., s. 57-59). Z kolei znacznie późniejsza księga cechu rzeźników Proszowic z XVII-XVIII w. znajduje się w ANK, 29/121/0/ Variae..., sygn. 29/121/0/-/324. Według archiwalnego opisu inwentarzowego zawiera wpisy z lat 1653-1779. Zob.: https://www.szukajwarchiwach.gov. pl/jednostka/-/jednostka/14663550 [dostęp: 20.11.2019].

${ }^{77}$ Przy edycji przyjęć do prawa miejskiego Proszowic z XV w. został sporządzony wykaz rąk pisarskich (K. Nabiałek, Registrum hominum..., s. 154). Według zastosowanej tam numeracji w równolegle prowadzonych aktach rady oraz w aktach ławniczych uchwytne są: ręka nr 17 - w 1. 1449-1451 (ANK, 29/121/0/ Variae..., sygn. 29/121/0/-/166, s. 201-222; sygn. 29/121/0/-/167, s. 1-43; BPAU, rkps 440, k. 115-122v); ręka nr 18 - w 1. 1451-1452 (ANK, 29/121/0/ Variae..., sygn. 29/121/0/-/166, s. 222-227; sygn. 29/121/0/-/167, s. 43-100); ręka 20 - 1454 r. (ibidem, sygn. 29/121/0/-/166, s. 186, 187, 197, 231, 232; sygn. 29/121/0/-/167, s. 101-112). 
w drugiej księdze pod datą tego samego sądu wpisy są zamieszczone ${ }^{78}$. Swoista symetria obu rękopisów dotyczy również formy zewnętrznej: wpisy rozpoczynają się w każdym z nich od strony 5 , a nagłówki sądu o identycznej treści są poprzedzone podobną inwokacją: I. N. R. I. In nomine Domini amen. Rękopis o sygn. 163, pomimo bogatej renesansowej okładki, został założony dla wpisów czasowych, głównie zobowiązań finansowych, kwitacji, przysiąg; są w nim też oblaty testamentów i inwentarzy mieszczańskich, a także dokumentów sądowych - m.in. wyroków sądu wyższego prawa niemieckiego z Krakowa. Z kolei rękopis o sygn. 164 pomimo dość prostej, surowej okładki z desek, stanowi rodzaj księgi wieczystej, gdyż zawiera wpisy dotyczące alienacji nieruchomości - kupna-sprzedaży, zamian, darowizn oraz rezygnacji. Wpisy w obu księgach dokonywane były przez te same osoby, a więc przez pisarzy miejskich z danego okresu. Dodajmy, że wprowadzane w rękopisie o sygn. 163 późniejsze, datowane noty o wypełnieniu zobowiązań (np. spłaceniu długów), są sporządzone rękami pisarzy, którzy redagowali w konkretnym czasie rękopis 164.

Co najmniej od ostatniej ćwierci XVI w. wykształciła się odrębna księga dokumentująca sprawy karne rozpatrywane przez sąd wójtowsko-ławniczy oraz przez urząd radziecki, tj. księga kryminalna. Niewątpliwie z powodu małej liczby spraw dotyczących ciężkich przestępstw, księga ta obejmowała długi okres (ponad 100 lat) - podobnie zresztą jak w innych miastach, dla których zachował się ten typ akt miejskich (Miechów, Nowy Wiśnicz, Nowy Sącz, Biecz, Przemyśl) ${ }^{79}$.

Zbadania wymaga ewolucja ksiąg miejskich Proszowic w XVII i XVIII w. Zachowały się one wprawdzie szczątkowo, ale pewne szanse na poszerzenie wiedzy o nich dają dokumenty i ekstrakty z ksiąg miejskich, zachowane m.in. w Archiwum Narodowym w Krakowie ${ }^{80}$ oraz w Bibliotece Naukowej PAU i PAN w Krakowie ${ }^{81}$, a kwerenda w innych kolekcjach rękopiśmiennych zapewne pozwoli na odnalezienia dalszych. Nawet wstępne przejrzenie rękopisów ksiąg pozwala na pewne wnioski dotyczące kancelarii miejskiej w tym czasie. $\mathrm{Na}$ podstawie pisma zachowanego $\mathrm{w}$ równolegle prowadzonych księgach radzieckich i ławniczych można stwierdzić, że obie serie - przynajmniej w pewnych okresach (np. 1. 1670-1671) - były redagowane przez jednego (wspólnego) pisarza, czyli podobnie jak w XV w.

${ }^{78} \mathrm{~Np}$.: pod datą sądu wyłożonego 7 marca 1567 r. w rękopisie 163 są wpisy na s. 20-25, a w rękopisie 164 na s. 10 jest tylko sam nagłówek; odwrotnie - pod datą sądu wyłożonego 18 lutego $1569 \mathrm{r}$. w rękopisie 163 na s. 129 jest tylko data - bez wpisów, zaś w drugim o sygnaturze 164 są wpisy na s. 44-46.

${ }^{79}$ M. Mikołajczyk, Proces kryminalny..., s. 19-20.

${ }^{80}$ ANK, 29/121/0/ Variae..., sygn. 29/121/0/-/281 (dawna sygn. IT 277). W jednostce tej, oprócz już wcześniej opisanych fragmentów ksiąg, na s. 389-1405 znajdują się liczne dokumenty miejskie z XVI-XVIII w. (głównie ekstrakty z ksiąg ławniczych i radzieckich).

${ }^{81}$ Ekstrakty z ksiąg miejskich Proszowic z XVIII i XIX w. obok innych dokumentów znajdują się w jednostce: BPAU, rkps 7126; zob. E. Knapek, Rękopisy średniowieczne..., s. 45. 
Kończąc uwagi na temat zachowanych ksiąg miejskich Proszowic, warto ponowić postulat zinwentaryzowania lub skatalogowania zachowanych ksiąg miast polskich z okresu przedrozbiorowego. Przykład Proszowic przekonuje, że inwentarz tego typu źródeł nie powinien ograniczać się jedynie do średniowiecza, ale powinien być realizowany dla całej epoki staropolskiej, tj. do końca XVIII w. ${ }^{82}$ Rozproszenie wytworów kancelarii miejskich powoduje, że technicznie inwentaryzację rękopisów ksiąg najlepiej byłoby sporząazać nie dla poszczególnych miast, lecz poprzez kwerendy w poszczególnych archiwach, bibliotekach, muzeach i innych kolekcjach, zbierając wszystkie zachowane tam rękopisy miejskie i ich fragmenty, a dopiero później - po zakończeniu poszukiwań - zestawić wyniki i zbudować na ich podstawie syntetyczny katalog albo bazę elektroniczną ${ }^{83}$. Warto zauważyć, że projekt opracowania elektronicznego inwentarza kodeksów bibliotecznych jest już realizowany, ale z założenia nie obejmuje ksiąg miejskich. Są tam inwentaryzowane wyłącznie „rękopiśmienne poprzedniczki książki drukowanej”, a więc głównie dzieła z zakresu literatury i ówczesnej nauki ${ }^{84}$.

\section{Źródła}

Archiwum Narodowe w Krakowie

29/10/0 Sąd wyższy prawa niemieckiego na zamku krakowskim 1390-1794, seria 29/10/0/2.1 Akta (indukty) 1390-1641, sygn. 29/10/0/2.1/8 (dawne sygn. SWPM I-8, Teut. 1a).

29/121/0 Variae civitates et villae - zbiór szczątków zespołów 1340-1969, sygn. 29/121/0/-/111, 29/121/0/-/112, 29/121/0/-/160, 29/121/0/-/161, 29/121/0/-/162, 29/121/0/-/163,

${ }^{82}$ Daty rozbiorów, które w periodyzacji dziejów ojczystych wyznaczają koniec epoki staropolskiej, nie są tak oczywistą cezurą w badaniach nad miastami. Badacze wskazują jednak, że choć początkowo ustrój miast pozostawał bez zmian, to jeszcze przed końcem XVIII w., zwłaszcza w monarchii habsburskiej, zaczęto stopniowo wprowadzać modyfikacje w zakresie administracji, sądownictwa oraz funkcjonowania kancelarii, a także archiwizacji produkcji kancelaryjnej. Zob.: K. Arłamowski, Kancelarie zarzadów miejskich $w$ zaborze austriackim w latach 1772-1918, „Archeion” 1962, t. 38, s. 244-248; S. Grodziski, Historia ustroju społeczno-politycznego Galicji 1772-1848, Wrocław 1971, s. 51-56; idem, Zabór austriacki, [w:] Historia państwa i prawa Polski, t. 3. Od rozbiorów do uwłaszczenia, red. J. Bardach, M. Senkowska-Gluck, Warszawa 1981, s. 679-680, 699-700; A. Bartoszewicz, Średniowieczne księgi sądowe..., s. $159-162$.

${ }^{83}$ Sposób gromadzenia materiału źródłowego opartego na zbiorach konkretnego archiwum stosują z powodzeniem sfragistycy, opracowując katalogi pieczęci. Zob. M. Hlebionek, Katalog pieczęci przy dokumentach samoistnych w zasobie Archiwum Państwowego w Bydgoszczy, Warszawa 2012; Zbiór tłoków i stempli pieczętnych w zasobie Archiwum Państwowego w Poznaniu, oprac. zbior., red. P. Pokora przy współpracy M. Hlebionka, Poznań 2015.

${ }^{84}$ J. Soszyński, Pierwszy rok prac nad „Inwentarzem dziedzictwa narodowego $w$ zakresie rękopisów średniowiecznych", [w:] Textus et pictura. Średniowieczny kodeks rękopiśmienny jako nośnik treści, znaczeń i wartości artystycznych, red. M. Jakubek-Raczkowska, M. Czyżak, Toruń 2019, s. $337-351$. 
29/121/0/-/164, 29/121/0/-/165, 29/121/0/-/166, 29/121/0/-/167, 29/121/0/-/281, $29 / 121 / 0 /-/ 324$.

Biblioteka Naukowa Polskiej Akademii Umiejętności i Polskiej Akademii Nauk w Krakowie, rękopisy: 440, 588, 702, 1207, 7126.

Biblioteka Jagiellońska w Krakowie, rękopis 1111.

\section{Bibliografia}

Akta miasta Przemyśla (1356-1389), 1402-1944 (1945-1983), t. 2, oprac. J. Krochmal, Przemyśl 2000.

Arłamowski K., Kancelarie zarządów miejskich w zaborze austriackim w latach 1772-1918, „Archeion" 1962, t. 38, s. 244-248.

Archiwum Akt Dawnych miasta Lwowa. A: Oddział Staropolski, t. 3. Księgi i akta administracyjno-sadowe 1382-1787; t. 4. Księgi rachunkowe (lonerskie) 1404-1788, oprac. K. Badecki, Lwów 1935-1936.

Bartoszewicz A., Czas w matych miastach. Studium z dziejów kultury umysłowej późnośredniowiecznej Polski, Warszawa-Pułtusk 2003.

Bartoszewicz A., Piśmienność mieszczańska w średniowiecznej Polsce, Warszawa 2012.

Bartoszewicz A., Średniowieczne księgi sądowe polskich miast - dzieje powstania zespołów i kolekcji, [w:] Dziedzictwo utracone - dziedzictwo odzyskane, red. A. Kamler, D. Pietrzkiewicz, Warszawa 2014, s. 159-173.

Bartoszewicz A., Urban literacy in late medieval Poland, Turnhout 2017 (Utrecht studies in medieval literacy 39).

Bielecka J., Inwentarze ksiąg archiwów grodzkich i ziemskich Wielkopolski XIV-XVIII wieku. Województwa poznańskie, kaliskie, gnieźnieńskie, inowrocławskie, Poznań 1965.

Briquet C.M., Les Filigranes dictionnaire historique des marques du papier dès leur apparation vers 1282 jusqu 'en 1600, t. 4, Paris-Genève 1907.

Der Wasserzeichenkartei Piccard im Huptsaatsarchiv Stuttgart, Bearbaitet von G. Piccard, t. 3. Die Turmwasserzeichen, Stuttgart 1970.

Czubek J., Katalog rękopisów Akademii Umiejętności w Krakowie, Kraków 1906.

Dziwik K., Jan Wincenty Smoniewski, historyk - zbieracz - bibliofil (1793-1867), „Rocznik Biblioteki Polskiej Akademii Nauk w Krakowie" 1963, r. 9, s. 97-109.

Friedberg M., Kancelaria miasta Krakowa do połowy XVIII wieku, „Archeion” 1955, t. 24, s. $277-$ 304.

Friedberg M., Kancelaria miasta Kazimierza pod Krakowem 1355-1802, „Archeion” 1962, t. 36, s. $137-170$.

Grodziska K., Zespót rękopisów średniowiecznych Biblioteki Naukowej PAU i PAN w Krakowie, [w:] Polska i jej sąsiedzi w późnym średniowieczu, red. K. Ożóg, S. Szczur, Kraków 2000, s. 395-413.

Grodziski S., Historia ustroju społeczno-politycznego Galicji 1772-1848, Wrocław 1971.

Grodziski S., Zabór austriacki, [w:] Historia państwa i prawa Polski, t. 3. Od rozbiorów do uwłaszczenia, red. J. Bardach, M. Senkowska-Gluck, Warszawa 1981. 
Grulkowski M., Definicja i klasyfikacja ksiag miejskich. Księgi w kancelariach miast obszaru Hanzy, [w:] Nauki pomocnicze historii. Teoria, metody badań, dydaktyka, red. A. Jaworska, R. Jop, Warszawa 2013, s. 119-148.

Hlebionek M., Katalog pieczęci przy dokumentach samoistnych w zasobie Archiwum Państwowego w Bydgoszczy, Warszawa 2012.

Inwentarz archiwum miasta Kazimierza pod Krakowem 1335-1802, oprac. M. Friedberg, Warszawa 1966.

Inwentarz archiwum miasta Kleparza pod Krakowem 1366-1794, oprac. Z. Wenzel-Homecka i Z. Wojas, Warszawa 1968.

Katalog Archiwum Aktów Dawnych miasta Krakowa, [t.] 2. Rękopisy. Nr. 1-3568, Kraków 1915 (oprac. zbior. przygotowane przez zespół archiwistów pod red. S. Krzyżanowskiego).

Kiryk F., Dzieje Proszowic w epoce piastowskiej i jagiellońskiej, „Rocznik Naukowo-Dydaktyczny Wyższej Szkoły Pedagogicznej w Krakowie. Prace Historyczne” 1967, z. 3, s. 21-49.

Kiryk F. Miasto średniowieczne, [w:] Proszowice. Zarys dziejów do 1939 roku, red. F. Kiryk, Kraków 2000, 47-91.

Knapek E., Akta oficjalatu i wikariatu generalnego krakowskiego do połowy XVI wieku, Kraków 2010.

Knapek E., Rękopisy średniowieczne w zbiorach Biblioteki Naukowej PAU i PAN w Krakowie, „Rocznik Biblioteki Naukowej PAU i PAN w Krakowie” 2012, r. 57, s. 9-47.

Krochmal J., Akta miasta Przemyśla (1402-1944), t. 1. Przewodnik po zespole archiwalnym, Przemyśl 1995.

Laberschek J., Lelów, [w:] Stownik historyczno-geograficzny województwa krakowskiego w średniowieczu, cz. 3, Kraków 1994, s. 510-512.

Leśniak F., W okresie Polski szlacheckiej, [w:] Proszowice. Zarys dziejów do 1939 roku, red. F. Kiryk, Kraków 2000, s. 115-146.

Lisowicz-Żurek D., Kancelaria małego miasta - organizacja, funkcje, znaczenie na przykładzie Chrzanowa w XV-XVI wieku, „Średniowiecze Polskie i Powszechne” 2015, t. 7(11), s. 228 240.

Łosowski J., Kancelarie miast szlacheckich województwa lubelskiego od XV do XVIII wieku, Lublin 1997.

Maisel W., Sądownictwo miasta Poznania do końca XVI wieku, Poznań 1961.

Mikołajczyk M., Proces kryminalny w miastach Małopolski XVI-XVIII wieku, Katowice 2013.

Mikołajczyk M., Przestepstwo i kara w prawie miast Polski południowej XVI-XVIII wieku, Katowice 1998.

Nabiałek K., Fragment zaginionej księgi ławniczej miasta Lelowa z drugiej połowy XV wieku, [w:] Narodziny Rzeczypospolitej. Studia z dziejów średniowiecza i czasów wczesnonowożytnych, Kraków 2012, s. 1293-1304.

Nabiałek K., Registrum hominum ius civile susceptorum. Rejestr przyjęć do prawa miejskiego Proszowic z XV wieku, „Średniowiecze Polskie i Powszechne” 2018, t. 10(14), s. 144-191.

Nabiałek K., Edycja rozproszonych wpisów przyjęć do prawa miejskiego na przykładzie Proszowic i Sieradza, [w:] Editiones sine fine, t. 2, red. K. Kopiński, J. Tandecki, Toruń 2020 [w druku]. 
Paloc-Schnaydrowa B., Cyprian Walewski. Bibliofil i kolekcjoner (1820-1873), „Rocznik Biblioteki Polskiej Akademii Nauk w Krakowie" 1958, r. 4, s. 367-389.

Piekosiński F., Średniowieczne znaki wodne zebrane z rękopisów przechowywanych $w$ archiwach i bibliotekach polskich, głównie krakowskich, wiek XIV, Kraków 1893.

Piskorska H., Organizacja władz i kancelarii miasta Torunia do 1793 roku, Toruń 1956.

Proksa M., Przewodnik po zespole Akta miasta Jarosławia, Przemyśl 1994.

Radtke I., Kancelaria miasta Poznania do roku 1570, Poznań 1967.

Samsonowicz H., Średniowieczne księgi sądowe matych miast w Polsce, [w:] Homines et societas. Czasy Piastów i Jagiellonów. Studia historyczne ofiarowane Antoniemu Gąsiorowskiemu w sześćdziesiąta piąta rocznicę urodzin, Poznań1997, s. 477-484.

Smołka J., Katalog Archiwum Aktów Dawnych miasta Przemyśla, Przemyśl 1927.

Smołka J., Katalog Archiwum Aktów Dawnych miasta Jarosławia, Jarosław 1928.

Soszyński J., Pierwszy rok prac nad ,Inwentarzem dziedzictwa narodowego w zakresie rękopisów średniowiecznych”, [w:] Textus et pictura. Średniowieczny kodeks rękopiśmienny jako nośnik treści, znaczeń $i$ wartości artystycznych, red. M. Jakubek-Raczkowska, M. Czyżak, Toruń 2019, s. 337-351.

Stankowa M., Kancelaria miasta Lublina XIV-XVIII wieku, Warszawa 1968.

Starzyński M., Nad średniowiecznymi księgami rachunkowymi, „Roczniki Historyczne” 2008, r. 74, s. $165-178$.

Starzyński M.. Średniowieczny Kazimierz, jego ustrój i kancelaria, Kraków 2015.

Tandecki J., Dokumenty i kancelarie miejskie, [w:] Dyplomatyka staropolska, red. T. Jurek, Warszawa 2015, s. 407-446.

Testamenty z ksiag sądowych matych miast polskich do 1525 roku, oprac. A. Bartoszewicz, K. Mrozowski, M. Radomski, K. Warda, red. A. Bartoszewicz, Warszawa 2017.

Wisłocki W., Katalog rękopisów Biblioteki Uniwersytetu Jagiellońskiego, cz. 1, Kraków 1877.

Wolff A., Akta partykularne przedrozbiorowe Archiwum Gtównego 1381-1835, [w:] Straty archiwów i bibliotek warszawskich w zakresie rękopiśmiennych źródeł historycznych, t. 1. Archiwum Gtówne Akt Dawnych, red. A. Stabelski, Warszawa 1957, s. 175-221.

Wyrozumska B., Kancelaria miasta Krakowa w średniowieczu, Kraków 1995.

Zbiór tłoków i stempli pieczętnych w zasobie Archiwum Państwowego w Poznaniu, oprac. zbior., red. P. Pokora przy współpracy M. Hlebionka, Poznań 2015.

\section{Bazy internetowe}

Baza filigranów Hauptstaatsarchiv Stuttgart, opracowana na podstawie wydawnictwa Piccarda www.piccard-online.de

Baza „Wasserzeichen des Mittelalters” Österreichische Akademie der Wissenschaft - https://www. wzma.at 